\title{
QUANTITATIVE APPLICATION OF THE WHOLE-PLANT CONCEPT TO THE MESSINIAN - PIACENZIAN FLORA OF ITALY
}

\author{
EDOARDO MARTINETTO ${ }^{1, *}$, LOREDANA MACALUSO $^{1}$ \\ ${ }^{1}$ Dipartimento di Scienze della Terra, Università degli Studi di Torino, Via Valperga Caluso 35, I-10125 Torino, Italy; \\ e-mail: edoardo.martinetto@unito.it, loredana.macaluso@edu.unito.it. \\ * corresponding author
}

Martinetto, E., Macaluso, L. (2018): Quantitative application of the Whole-Plant Concept to the Messinian - Piacenzian flora of Italy. - Fossil Imprint, 74(1-2): 77-100, Praha. ISSN 2533-4050 (print), ISSN 2533-4069 (on-line).

\begin{abstract}
The analysis of a taxonomical database containing Italian pollen and macrofossil records of the Messinian - Piacenzian time interval allowed us to evaluate the possible assemblage of different parts within a Whole-Plant Concept. The fossil plant parts that we deemed more significant were: "herbarium-like" specimens, foliage, female and male reproductive organs and stem parts (mainly woody axes). When it has been possible, we recognized these different parts as putative products of a single ancient plant species. Then we operated a random selection of 100 taxonomical entities (potential whole-plant taxa, indicated by the progressive numbers WP001, WP002, etc.) and we analysed their fossil record in order to quantify the proportion of ancient plants represented by one, two or more different parts in the fossil record of the studied area and time slice. Our quantitative analysis showed that $63 \%$ of the potential whole-plant taxa are represented by a single type of plant part, $23 \%$ are represented by two plant parts, and $14 \%$ by three or more different parts. A few taxa were selected as examples to show in detail the implications of applying the Whole-Plant Concept; this involved a taxonomic discussion of Actinidia, Ailanthus, Engelhardia, Eucommia, Glyptostrobus and Taxodium.
\end{abstract}

Key words: fossil-taxa, plant organs, Whole-Plant Concept, Miocene, Pliocene, Italy

Received: January 17, 2018 | Accepted: March, 22, 2018 | Issued: August 31, 2018

\section{Introduction}

The reconstruction of terrestrial floras of the past is strongly hampered and complicated by the fact that the fossil record of plant taxa consists mainly of various types of fragments. A comparison with modern floras (e.g. Bartolucci et al. 2018), made up by living plant taxa which are usually collected as flowering or fruiting specimens of whole organisms, is therefore very difficult. The Whole-Plant Concept aims to investigate the relationships among most of the detached fossil plant organs, never found in organic connection, by following a few lines of evidence as listed by Kvaček (2008: 919).

The Whole-Plant Concept, after Kvaček (2008), does not necessarily imply that a pictorial reconstruction of an ancient plant taxon will be obtained (as in Bomfleur et al. 2013), but sometimes just to consider the possible combination of different fossil plant parts (Kvaček and Hably 2014), as components of a single ancient "whole-plant". Teodoridis and Sakala (2008) pointed out that the principles of this holistic approach had been demonstrated for the Cenozoic of Europe by Kvaček (2004) for leaves and reproductive organs, and by Sakala (2004) for the association of wood with other organs.
Kvaček et al. (2004) examined such combinations for several fossil plant taxa from a Central European Neogene flora, and Teodoridis and Sakala (2008) provided an excellent overview of conifer whole-plant taxa from a sedimentary basin in Central Europe. However, a more quantitative approach, based on a representative sample of fossil floras from a broad area, to our knowledge has not yet been attempted and may be considered worthwhile for different purposes. Therefore, we decided to test a quantitative application of the WholePlant Concept to Messinian - Piacenzian macrofossil and pollen records of north and central Italy (Text-fig. 1). This is a suitable situation due to the enormous number of localities, yielding a dense chronological and geographic coverage of fossil plant assemblages (Bertini 2010, Bertini and Martinetto 2011, Martinetto 2015), which represent the disarticulated parts produced by the Neogene plant communities.

\section{Material and methods}

For the analysis of the possible combinations of different plant parts from the Messinian - Piacenzian of Italy we used 


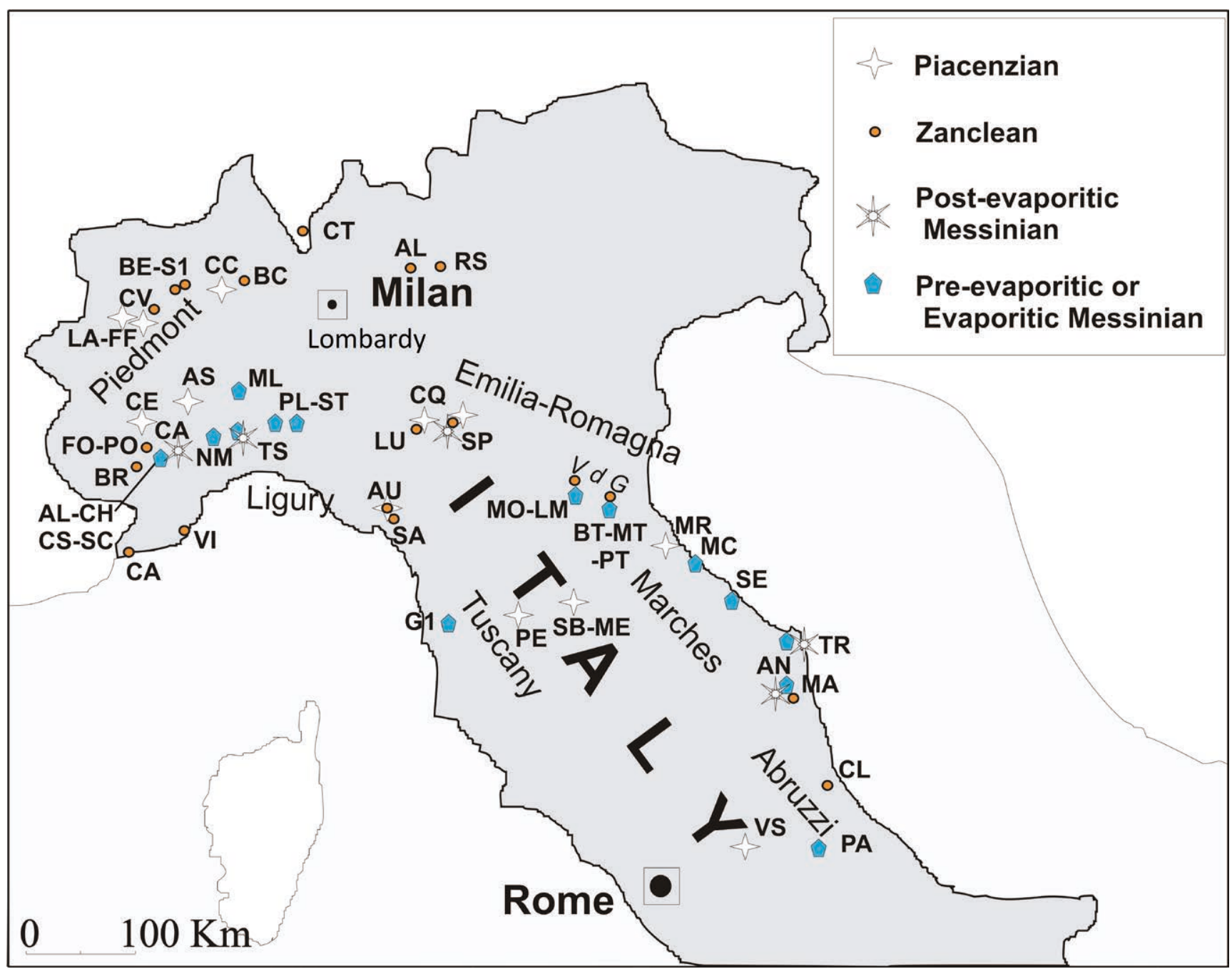

Text-fig. 1. Map of northern and central Italy showing the location of the main sites with relevant Messinian to Piacenzian fossil floras. For locality labels see explanation in Table 1.

a pollen and macroflora database compiled by Bertini and Martinetto (2011), integrated with recent data by Macaluso et al. (2018), Martinetto et al. (2015, 2018) and Teodoridis et al. (2015a, b, 2017a, b). One of the main alterations involved the inclusion of data concerning a few fossil floras of the preevaporitic Messinian (7.25-5.61 Ma). We also verified that in the updated chronostratigraphic chart (Cohen et al. 2013 [updated 2017]) there are no changes in the boundaries of the chronostratigraphic stages used by Bertini and Martinetto (2011) for the Messinian - Piacenzian interval (Tab. 1). Therefore, in Table 2, we were able to use the chronological framework reported in Bertini and Martinetto (2011), and we assigned to the appropriate time slices the new occurrence data provided by Macaluso et al. (2018), Martinetto et al. $(2015,2018)$ and Teodoridis et al. (2015a, b, 2017a, b). Only the locality "Gabbro" requires individual discussion because it yielded two distinct flora-bearing layers (Kovar-Eder et al. 2006) which have had inconsistent stratigraphic assignment (Kovar-Eder et al. 2006, Bertini and Martinetto 2008, Bertini and Martinetto 2011). For this reason, as already presented by Bertini and Martinetto (2011), we also excluded the Gabbro I site, and considered only the Gabbro II site in this paper (locality Pane e Vino: Berger 1958), which was tentatively assigned to the post-evaporitic Messinian (5.61-5.33 Ma).
The updated Bertini and Martinetto (2011) database includes most of the recently revised pollen, carpological, wood and leaf fossil-taxa of several Messinian - Piacenzian localities in northern/central Italy (Tab. 1) and follows the nomenclature applied in the Italian Neogene, in which carpological material, wood and leaves are usually assigned to fossil-species (see McNeill et al. 2012 for the fossilspecies concept), whereas pollen grains are usually identified at genus or family level (Bertoldi et al. 1994, Bertini 2010, Magri et al. 2017).

The ICN (McNeill et al. 2012) allows the use of separate fossil-species names for different isolated fossil plant organs, even if they may have been produced by the same ancient organism. The resulting nomenclatural practice may appear confusing to botanists, but the Whole-Plant Concept may help to clarify the relationship: some fossil-taxa, based on a single plant part (fragment of an ancient biological taxon), may be assembled into a hypothetic whole-plant, conceptually equivalent to a modern biological entity. Cleal and Thomas (2010) correctly pointed out that there are very real practical problems in formally naming extinct plants reconstructed from the fossil record because these assembled reconstructions are hypotheses and are not governed by the principle of priority (Miller et al. 2011). The best practice is to not name 


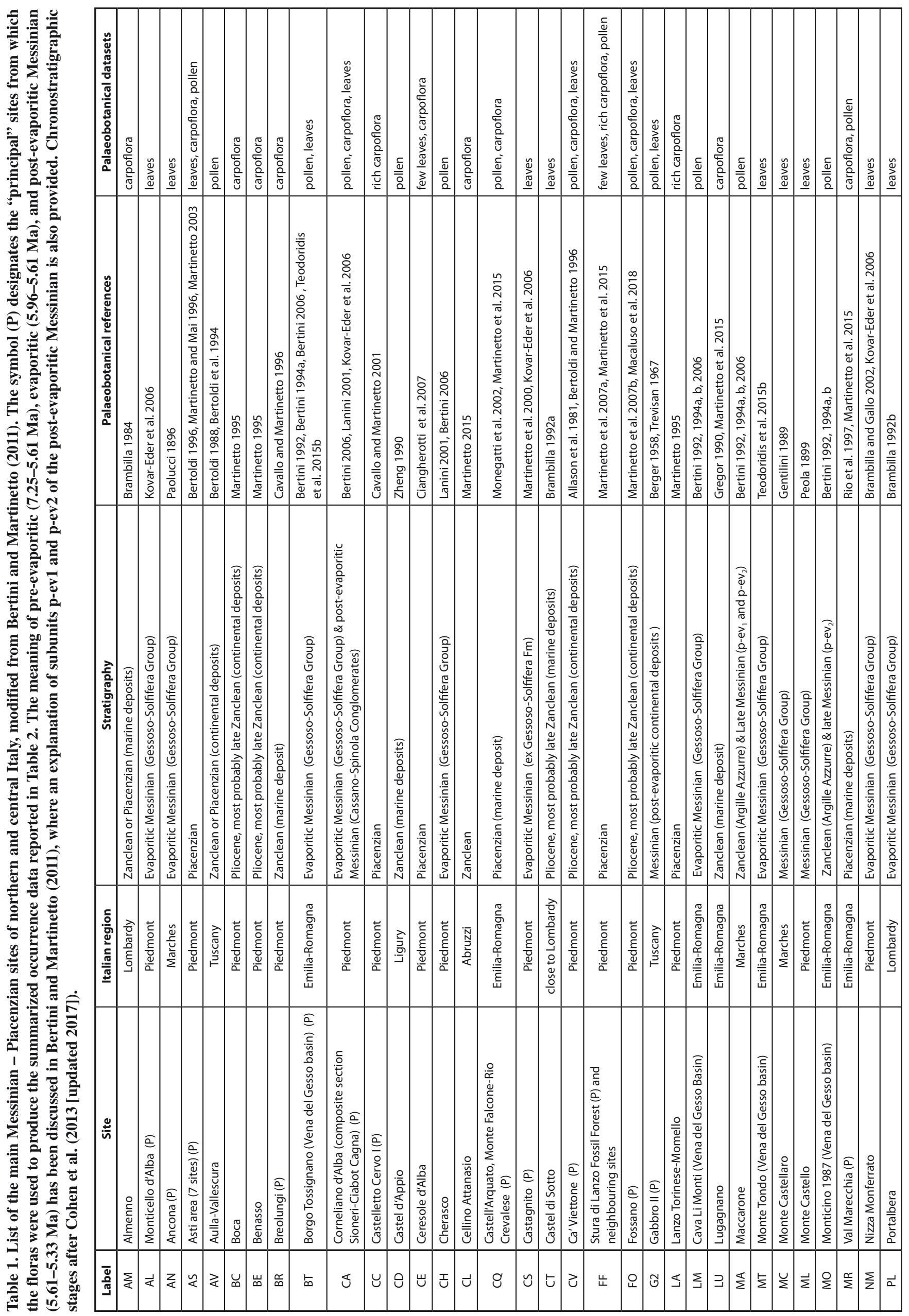




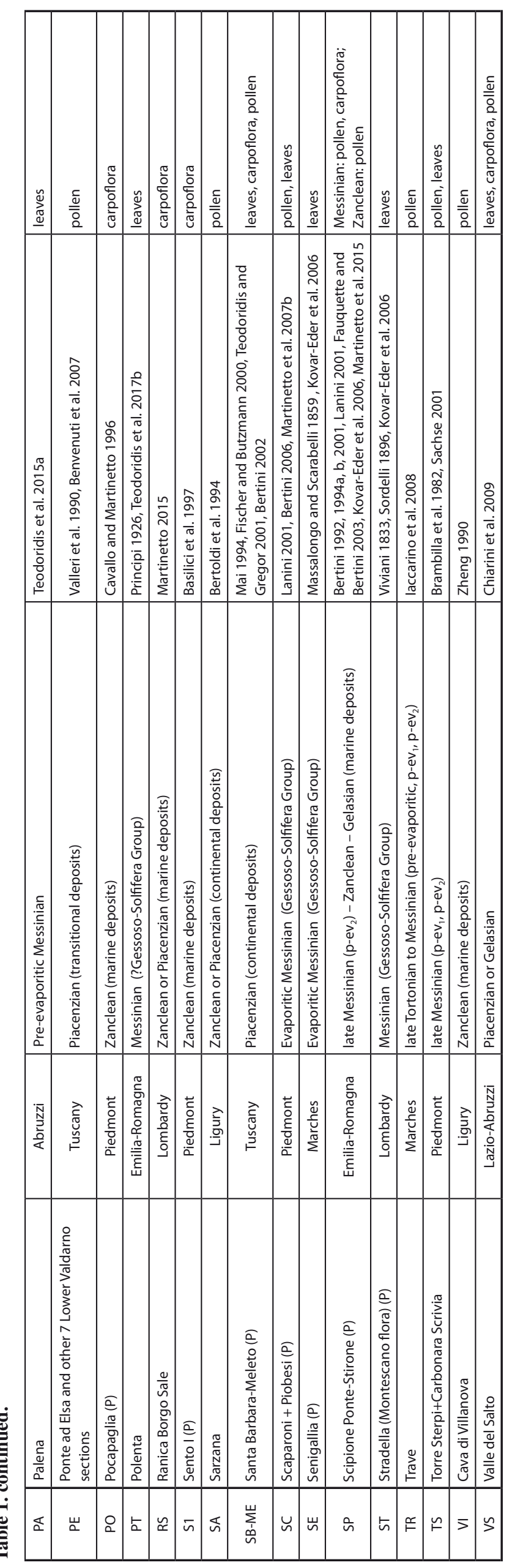

fossil plants formally at all, but to refer to them by names outside of a formally codified system of nomenclature (Cleal and Thomas 2010). Teodoridis and Sakala (2008) already provided good examples for the Cenozoic of Europe, and proposed to designate whole-plants, assembled from the fossil record of several organs, with such names as "Glyptostrobus europaeus plant", "Taxodium dubium plant", etc. In this paper, by following Vassio et al. (2008), we prefer to use "Glyptostrobus europaeus whole-plant", "Taxodium dubium whole-plant", etc., in order to point out unambiguously that the binomial names are used according to the Whole-Plant Concept illustrated by Kvaček (2008).

We quantitatively tested an application of the WholePlant Concept by using the Messinian - Zanclean records of the updated Bertini and Martinetto (2011) database, in which we did not include pre-Messinian records (e.g. Biondi et al. 1985, Hably 2010, Bonci et al. 2011). The first operation on the database consisted of grouping together the taxa represented by different plant organs, which could be assigned to a single fossil whole-plant based on the lines of evidence presented by Kvaček (2008: 919) and Manchester et al. (2014). Such lines were also adopted in this paper and codified with the following acronyms: RCO, repeated co-occurrence (either in the same locality or same chronostratigraphic interval); IEA, identical or similar epidermal anatomy; ISA, identical or similar systematic affinities, implemented by our knowledge of the wholeplant habitus of the living relatives (Manchester et al. 2014); PIS, pollen in situ and pollen ex situ (accumulations scraped from the surface of leaves).

Given the characteristics of our data, we could mostly apply the line ISA and more rarely RCO; whereas the lines IEA and PIS were not applicable because the necessary analyses had not yet been carried out on the Messinian Piacenzian of Italy. The whole-plant reconstruction of those taxa for which we used ISA (e.g. Lycopus; Text-fig. 2a, b) may be improved by the analysis of their position within the most consistent and detailed molecular- and morphologybased phylogenetic tree for the studied family (Text-fig. 2c). Of course, a whole-plant reconstruction may be supported by analysis of the habitus of those living relatives (Text-fig. 2d) which do not only belong to the nearest living species, but also to the "sister taxa" from a phylogenetic point of view. In phylogenetically isolated genera a simple analysis of the habitus of all the genus members may be sufficient. For example, Lycopus is a phylogenetically isolated genus within Mentheae (Drew and Sytsma 2012), therefore the habitus of a Pliocene species of Lycopus (Text-fig. 2b) may be deduced by that of the living species of this same genus. All species of Lycopus are herbs with opposite leaves and terminal inflorescences of zygomorphic flowers with two stamens, and this applies also to the majority of its sister taxa (e.g. Mentheae subtrib. div.; Drew and Sytsma 2012), although some representatives are small shrubs. Therefore, the fossil Lycopus cf. americanus was also most probably a herb with the same characters as the extant Lycopus species, whereas the shrubby habitus of some related Mentheae is less likely.

Moreover, when we exploited line ISA, we also considered that more abundant and/or complete fossils, similar to those from Italy treated in this paper, but often with a 


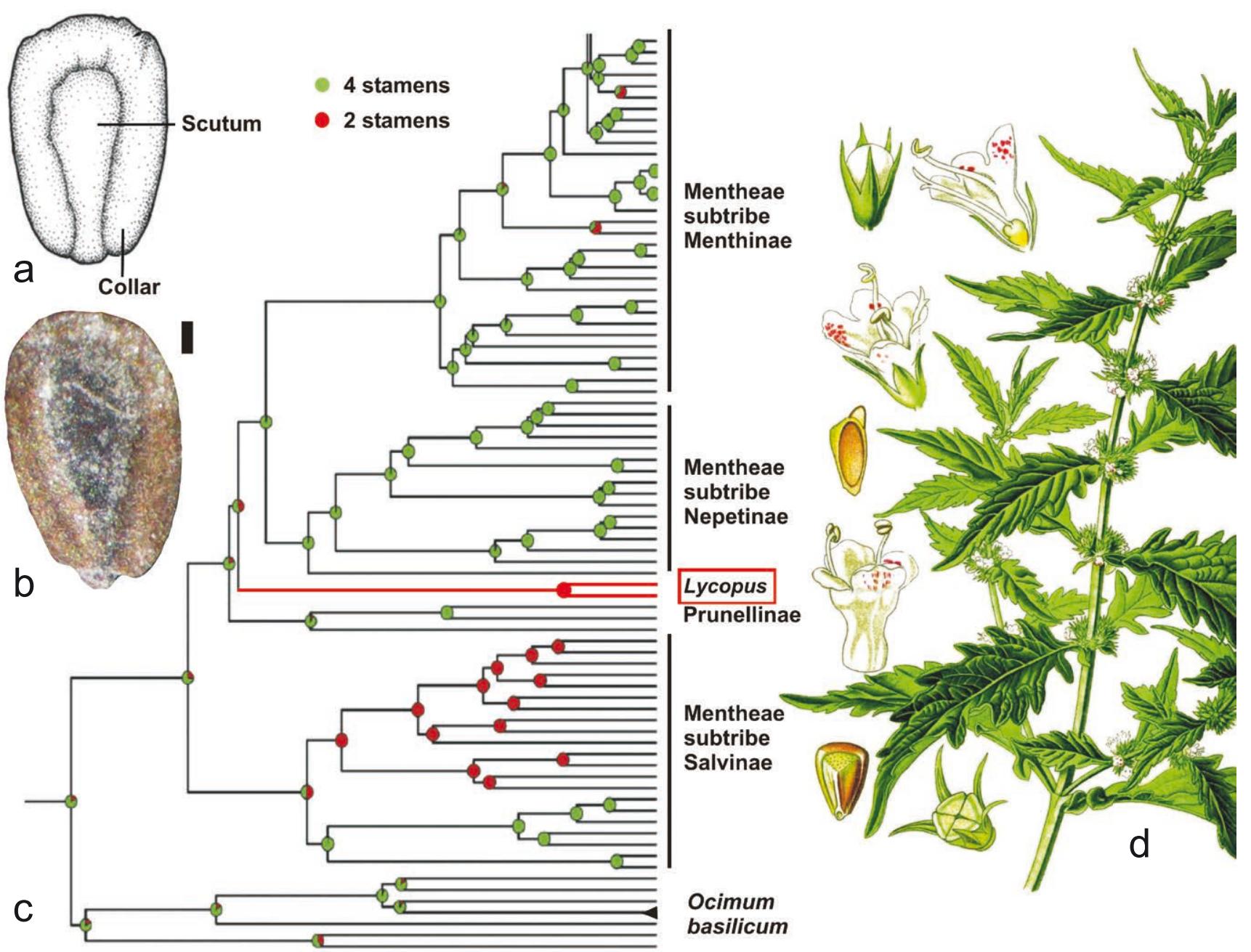

Text-fig. 2. Example of morphological characters of a single plant part which are diagnostic for its placement at a precise position of a phylogenetic tree. a) the presence of a collar around the nutlet (schematic drawing, dorsal view) is highly diagnostic for the genus Lycopus; b) fossil nutlet of Lycopus cf. americanus in dorsal view, early Pliocene of Ca' Viettone, NW Italy (Martinetto et al. 2018); c) phylogenetic tree of the tribe Mentheae, modified from Drew and Sytsma (2012); d) aspect of the living Lycopus europaeus L., most likely similar to that of the Pliocene Lycopus cf. americanus whole-plant. Illustration from Thomé (1885), improved by O. Tackenberg (http://www.i-flora.com).

larger number of associated parts (e.g. Eucommia europaea; Kvaček et al. 2008), can be found elsewhere in Europe (e.g. Hably 2001, Stuchlik 2001, Kovar-Eder et al. 2004, Kvaček et al. 2004, 2008, Teodoridis and Sakala 2008, Kunzmann et al. 2009). These records from outside Italy provide more definite lines of evidence for use of a Whole-Plant Concept for the fragmentary or scarce Italian fossil records. The fossil plant parts that we deemed more significant (Textfig. 3a-c) for assembling a Whole-Plant Concept are: (1) "herbarium-like" specimens (i.e. single fossils with several significant organs attached together, as shown in Manchester et al. (2014: 2)); (2) female reproductive organs, (3) foliage, (4) male reproductive organs, (5) stem parts (mainly woody axes). Additionally, roots and bark can be considered optional elements conceptualizing the whole-plant. The basic information provided by each plant part (Text-fig. 3ac) concerns its morphology, but other important data are the anatomical features, rarely available in the Italian material, and the variation, which can be studied only when several specimens occur.
For an effective synthesis of the fossil record of each potential whole-plant taxon we propose to use two connected tools: a whole-plant part table and a wholeplant identity plate. The table summarizes the information available for a particular whole-plant species, and the related plate provides images of the main fossil organs, as well as images of the reconstructed habitus of the plant or that of the living relatives. In this paper we show just a few examples of whole-plant part tables (Text-fig. 3a-c) and whole-plant identity plates (Text-figs 4-6). Both tables and plates contain empty boxes, when determinate fossil organs are lacking in the Italian fossil record. A complete set of such tables and plates would be useful for future preparation of a catalogue or atlas of Neogene whole-plant taxa in Italy, but it is beyond the scope of this article. Rather, the main aim of the present paper is to quantify the proportion of whole-plant taxa represented by one, two or more different parts in the studied area and time slice. For this purpose we analysed an interpretive taxonomical list in which progressive numbers (WP001, WP002, etc. in Tab. 2) were assigned to assembled 


\begin{tabular}{|c|c|c|c|}
\hline & & Taxon & \\
\hline & Whole-plant parts & Actinidia faveolata & \\
\hline 1 & herbarium-like specimens & & \\
\hline \multirow{3}{*}{2} & \multirow{3}{*}{ female reproductive organs } & morphology & $\mathbf{x}$ \\
\hline & & anatomy & \\
\hline & & variation & $\mathbf{x}$ \\
\hline \multirow{3}{*}{3} & \multirow{3}{*}{ foliage } & morphology & \\
\hline & & anatomy & \\
\hline & & variation & \\
\hline \multirow{3}{*}{4} & \multirow{3}{*}{ male reproductive organs } & morphology & \\
\hline & & anatomy & \\
\hline & & variation & \\
\hline \multirow{3}{*}{5} & \multirow{3}{*}{ stem } & morphology & \\
\hline & & anatomy & \\
\hline & & variation & \\
\hline \multirow{2}{*}{ 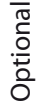 } & \multicolumn{2}{|l|}{ roots } & \\
\hline & \multicolumn{2}{|l|}{ bark } & \\
\hline
\end{tabular}

a

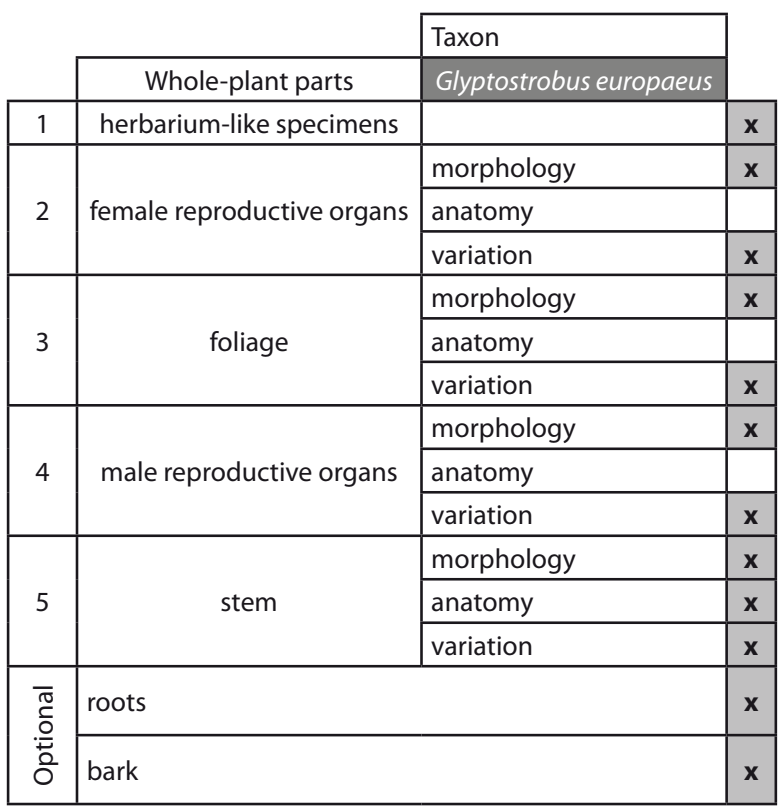

\begin{tabular}{|c|c|c|c|}
\hline & & \multirow{2}{*}{\multicolumn{2}{|c|}{ Taxon }} \\
\hline & & & \\
\hline & Whole-plant parts & Taxodium dubium & \\
\hline 1 & herbarium-like specimens & & \\
\hline \multirow{3}{*}{2} & \multirow{3}{*}{ female reproductive organs } & morphology & $\mathbf{x}$ \\
\hline & & anatomy & \\
\hline & & variation & $\mathbf{x}$ \\
\hline \multirow{3}{*}{3} & \multirow{3}{*}{ foliage } & morphology & $\mathbf{x}$ \\
\hline & & anatomy & \\
\hline & & variation & $\mathbf{x}$ \\
\hline \multirow{3}{*}{4} & \multirow{3}{*}{ male reproductive organs } & morphology & $\mathbf{x}$ \\
\hline & & anatomy & \\
\hline & & variation & $\mathbf{x}$ \\
\hline \multirow{3}{*}{5} & \multirow{3}{*}{ stem } & morphology & \\
\hline & & anatomy & \\
\hline & & variation & \\
\hline \multirow{2}{*}{ 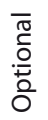 } & \multicolumn{2}{|l|}{ roots } & \\
\hline & \multicolumn{2}{|l|}{ bark } & \\
\hline
\end{tabular}

organs, tentatively representing a single biological plant species of the past, as already presented by Teodoridis and Sakala (2008). In the taxonomical list we focused on families whose name starts with the letters between A to M (with the exception of Simaroubaceae, added subsequently in order to suggest a possible combination between leaves of cf. Ailanthus pithii, which was considered family incertae sedis, and a fruit of Ailanthus confucii), and, by using the RAND formula in Microsoft Excel, we operated a random selection of 100 potential whole-plant taxa and analysed their fossil record (Tab. 2).

\section{Results}

The updated Bertini and Martinetto (2011) database which we analyzed contains occurrence data of fossil plant taxa plotted into a relatively definite chronological framework thanks to the chronostratigraphic assignment of several "principal" flora-bearing successions (Tab. 1). The chronological boundaries for each stage reported by Cohen et al. (2013 [updated 2017]: Tortonian $=11.63-7.25$ $\mathrm{Ma}$; Messinian = 7.25-5.33 Ma; Zanclean = 5.33-3.60 Ma; Piacenzian $=3.60-2.58 \mathrm{Ma}$; Gelasian $=2.58-1.80 \mathrm{Ma})$ and the subdivision of the Messinian reported by Bertini and Martinetto (2011: pre-evaporitic $=7.25-5.61 \mathrm{Ma}$; evaporitic $=5.96-5.61 \mathrm{Ma}$; post-evaporitic $=5.61-5.33 \mathrm{Ma}$ ) allowed us to build up a chart of the chronological distribution of 45 pollen taxa, 69 carpological taxa, 52 leaf taxa, 1 flower taxon and 2 wood taxa (low quantity due to the limited amount of wood taxonomical analyses in the Messinian - Piacenzian of Italy, with the exception of Biondi (1982) and Vassio et al. (2008)).

Each of the 100 entities we selected for the analysis (Tab. 2) contained at least the remains of one ancient wholeplant species, but of course those entities identified at genus or family level (e.g. Alnus, Apiaceae, Caryophyllaceae, Chenopodiaceae, Ericaceae) may have included the remains of an imprecise number of species of those given genera or families. We summarized synthetically the plant parts which are available for each whole-plant taxon by means of a number or a sum of numbers (corresponding to those in Text-fig. 3), which we propose to indicate as the "WholePlant Concept pattern" ("WPC pattern" in Tab. 2). We scored the WPC patterns by omitting the dubious association of a plant organ with others (indicated by question marks in Tab. 2 ), and our analysis of 100 randomly selected taxonomical entities from the Messinian - Piacenzian sites of Italy

Text-fig. 3. Examples of whole-plant part tables summarizing current knowledge on the morphology, anatomy and variation, in the Messinian to Piacenzian of Italy, of fossil parts of three sample taxa which show: a) only one category (Whole-Plant Concept $($ WPC $)$ pattern = 2) of plant parts available for a WholePlant Concept (Actinidia faveolata). b) all categories of plant parts (WPC pattern = 1 to 5), including the optional ones, available for a Whole-Plant Concept (Glyptostrobus europaeus). c) three (WPC pattern $=2+3+4$ ) out of five categories of plant parts available for a Whole-Plant Concept (Taxodium dubium). The numbers in the first column are used to summarize synthetically the Whole-Plant Concept (WPC) pattern in Table 2. 


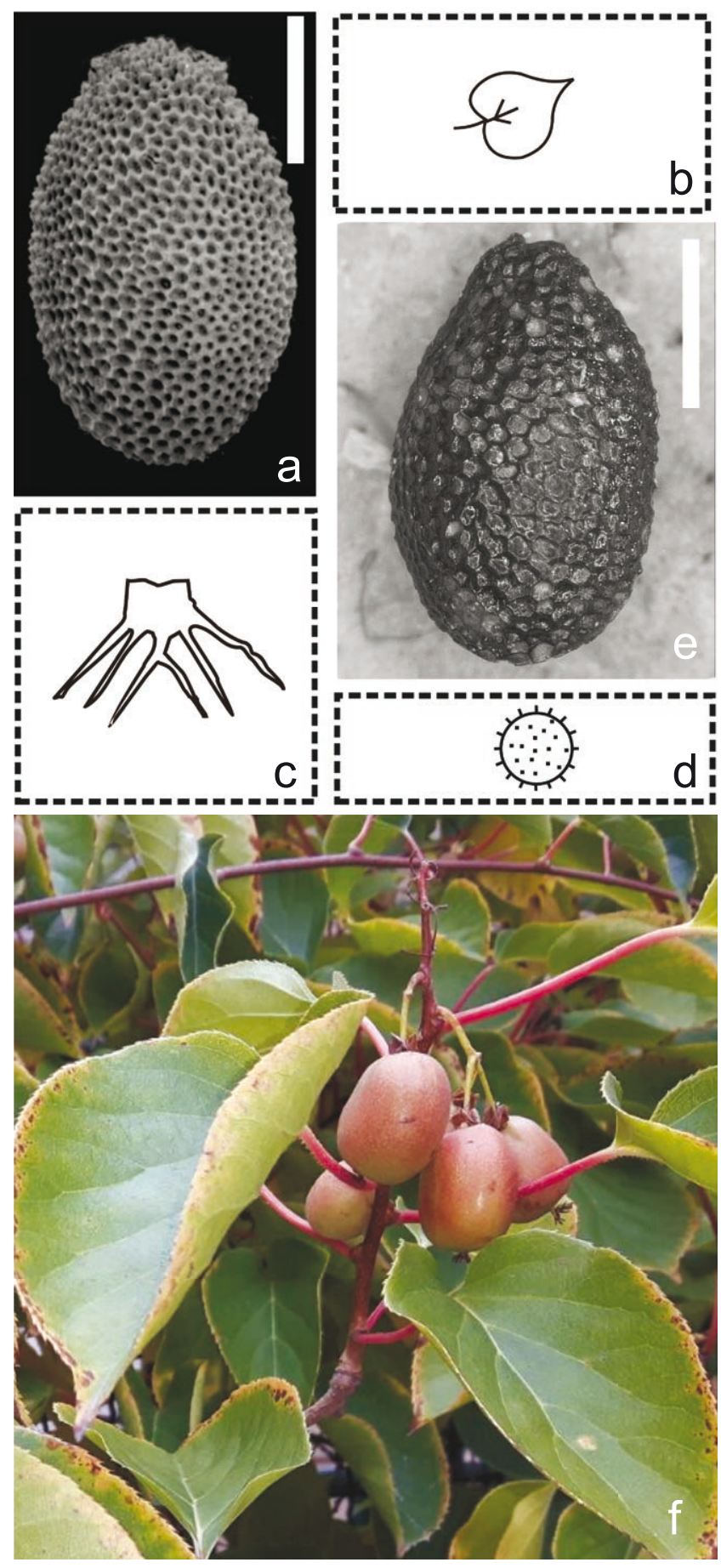

Text-fig. 4. Identity plate of the Actinidia faveolata wholeplant. The seed is the unique available fossil part. a) fossil seed of Actinidia faveolata from the Stura di Lanzo Fossil Forest (Martinetto et al. 2007a), Piacenzian of northern Italy. b) foliage remains lacking. c) remains of woody axes lacking. d) pollen remains lacking. e) modern seed of Actinidia arguta (from Hiroshima Bot. Garden), with a structure closely similar to Actinidia faveolata. f) aspect of a living plant of $A$. arguta with fruits and leaves, Botanical Garden of the Faculty of Science, Charles University, Prague. Scale bar 1 mm.

(potential whole-plant taxa) showed that $63 \%$ of the taxa are represented by a single type of plant organ, $23 \%$ are represented by two plant organs with a well-supported association, and $14 \%$ by three or more different organs with well-supported association (Tab. 3).

\section{Systematic palaeobotany}

Examples of different patterns of fossil record are provided by a few selected taxa extracted from the comprehensive list (Tab. 2). The discussion is focused on the Italian record of the Messinian - Piacenzian, and the occurrence of the same taxa outside this geographical and chronological context is only cited when this is fundamental to the Whole-Plant Concept of the studied fossils.

\section{Family Cupressaceae Gray, 1822}

\section{Genus Glyptostrobus ENDLICHER, 1847}

Glyptostrobus europaeus whole-plant

Glyptostrobus europaeus (BRONGNIART) UNGER (foliage shoots, cones, seeds); Glyptostroboxylon rudolphii

Dolezych et Burgh (wood); Taxodium-type pro parte (pollen)

Text-fig. 5a-h

Material. The Messinian sites mostly provided shoots, but infrequently. The Pliocene sites provided all types of macroremains, in large quantities in some fossil forests: Dunarobba, Fossano, La Cassa, Le Matole, Stura di Lanzo, Villafranca d'Asti - RDB Quarry (Vassio et al. 2008, Martinetto et al. 2007a, 2014, Bertini and Martinetto 2014, Forno et al. 2015, Macaluso et al. 2018). A proportion of the pollen grains of the Taxodium-type, frequent in most of the Messinian to Zanclean samples, was certainly produced by the Glyptostrobus europaeus whole-plant.

R e m a rks. Glyptostrobus europaeus is a fossil-species name (McNeill et al. 2012) first used for a shoot with cones from Greece (Miocene), preserved at the Muséum national d'Histoire naturelle of Paris (specimen MNHN.F.1744, holotype), but its extension to a Whole-Plant Concept was already discussed by Vassio et al. (2008) because of the cooccurrence of stumps, roots, trunks, foliage shoots, cones and seeds (Text-fig. 5a-f) in swamp forest palaeoenvironments (line of evidence RCO). Some of the fossil pollen referred to the "Taxodium-type" (Text-fig. 5g) in the Neogene of Italy was certainly produced by the "Glyptostrobus europaeus whole-plant". The habitus of this ancient plant can be reconstructed by integrating information on the large stumps and trunks, found in several fossil forests, with our knowledge of the modern relatives (line of evidence ISA), and also considering the phylogenetic framework ( $\mathrm{Lu}$ et al. 2014). The habitus of all the members of the Glyptostrobus phylogenetic clade is that of trees of medium to large height, of conical shape when young, with spirally arranged leaves and pear-shaped to globose cones. Therefore, the fossil Glyptostrobus europaeus was certainly a tree with such features, as illustrated in a pictorial reconstruction of the Dunarobba Fossil Forest (Martinetto et al. 2014) in central Italy (Text-fig. 5h). Its small cones were pear-shaped.

\section{Genus Taxodium Richard, 1810}

Taxodium dubium whole-plant

Taxodium dubium (STERnBerg) HeER (foliage shoot, cone, seed); Taxodium-type pro parte (pollen)

Text-fig. 6a-g 

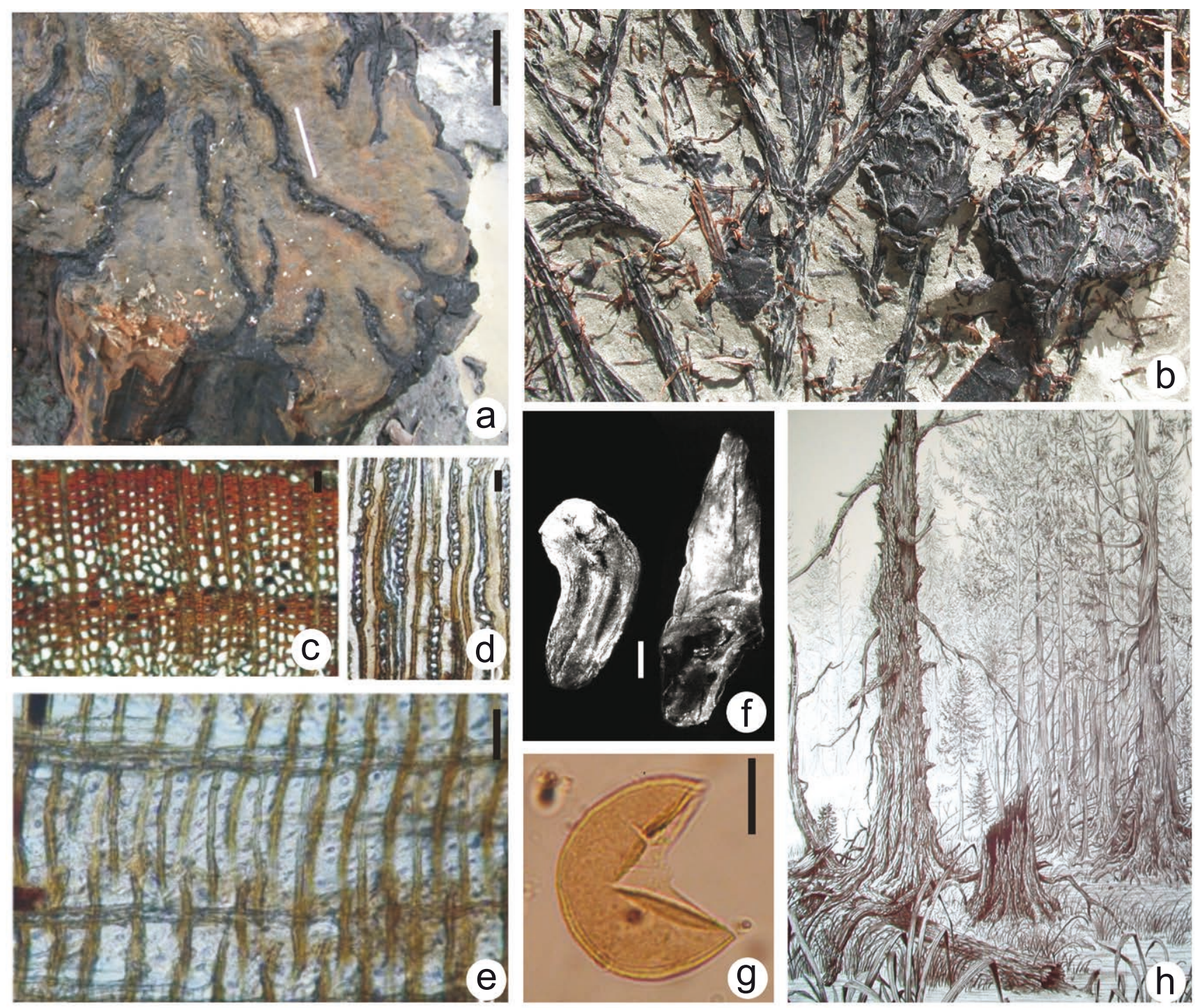

Text-fig. 5. Identity plate of the Glyptostrobus europaeus whole-plant. a) fossil remains of a woody axis: stump from the Stura di Lanzo Fossil Forest showing lobed xylem in cross section, surrounded by darker bark remains. b) foliage shoots with attached cones from the same site. c, d, e) wood cross sections, Stura di Lanzo Fossil Forest, respectively transversal, tangential and radial section (from Vassio et al. 2008). f) seeds, the right hand specimen with a preserved wing from the same site, the wingless specimen from Dunarobba. g) Taxodium-type pollen from the Stura di Lanzo Fossil Forest, photo courtesy of Nela Doláková. h) reconstruction of the Glyptostrobus europaeus whole-plants which formed the Dunarobba Fossil Forest, drawing by Angelo Barili. Scale bar 10 mm for $\mathrm{a}, \mathrm{b} ; \mathbf{5 0} \mu \mathrm{m}$ for $\mathrm{c}-\mathrm{e}, \mathbf{1} \mathrm{mm}$ for $\mathrm{f}$ and $20 \mu \mathrm{m}$ for $\mathrm{g}$.

Materia 1 . The Messinian sites only provided shoots. Five Pliocene sites provided a few types of remains, only at Villafranca d'Asti - RDB Quarry were there large quantities; less abundant shoot and cone specimens at: Arboschio, Castelnuovo Don Bosco, Meleto and Santa Barbara (Fischer and Butzmann 2000, Forno et al. 2015, Teodoridis and Gregor 2001). The pollen grains of the Taxodium dubium whole-plant are not distinguished from those of the Glyptostrobus europaeus whole-plant, and are subsumed under the Taxodium-type, frequent in most of the Messinian to Zanclean samples.

R e marks. The fossil-species name Taxodium dubium was first used for foliage shoots, but its application to a WholePlant Concept has already been discussed by Kunzmann et al. (2009), who reported the co-occurrence (line of evidence $\mathrm{RCO}$ ) of most of the organs. In a few Italian sites several parts co-occur: foliage shoots (Text-fig. 6a), cones (Text-fig. 6b), seeds (Text-fig. 6d), and pollen referred to the "Taxodiumtype" (Text-fig. 6f). Conversely, the stem parts (Text-fig. 6c) and pollen cones (Text-fig. 6e) of the Taxodium dubium whole-plant have not yet been reported. The habitus of this ancient plant, by considering the phylogenetic framework ( $\mathrm{Lu}$ et al. 2014), is necessarily similar to that of Glyptostrobus (see above), yet with globose cones. The fossil Taxodium dubium certainly had a similar habitus (Text-fig. 6g) as its living relative Taxodium distichum.

\section{Family Actinidiaceae Engler et GILG, 1924}

Genus Actinidia LindLey, 1836

Actinidia faveolata whole-plant Actinidia faveolata C. et E.REID (seed) Text-fig. $4 \mathrm{a}$ 


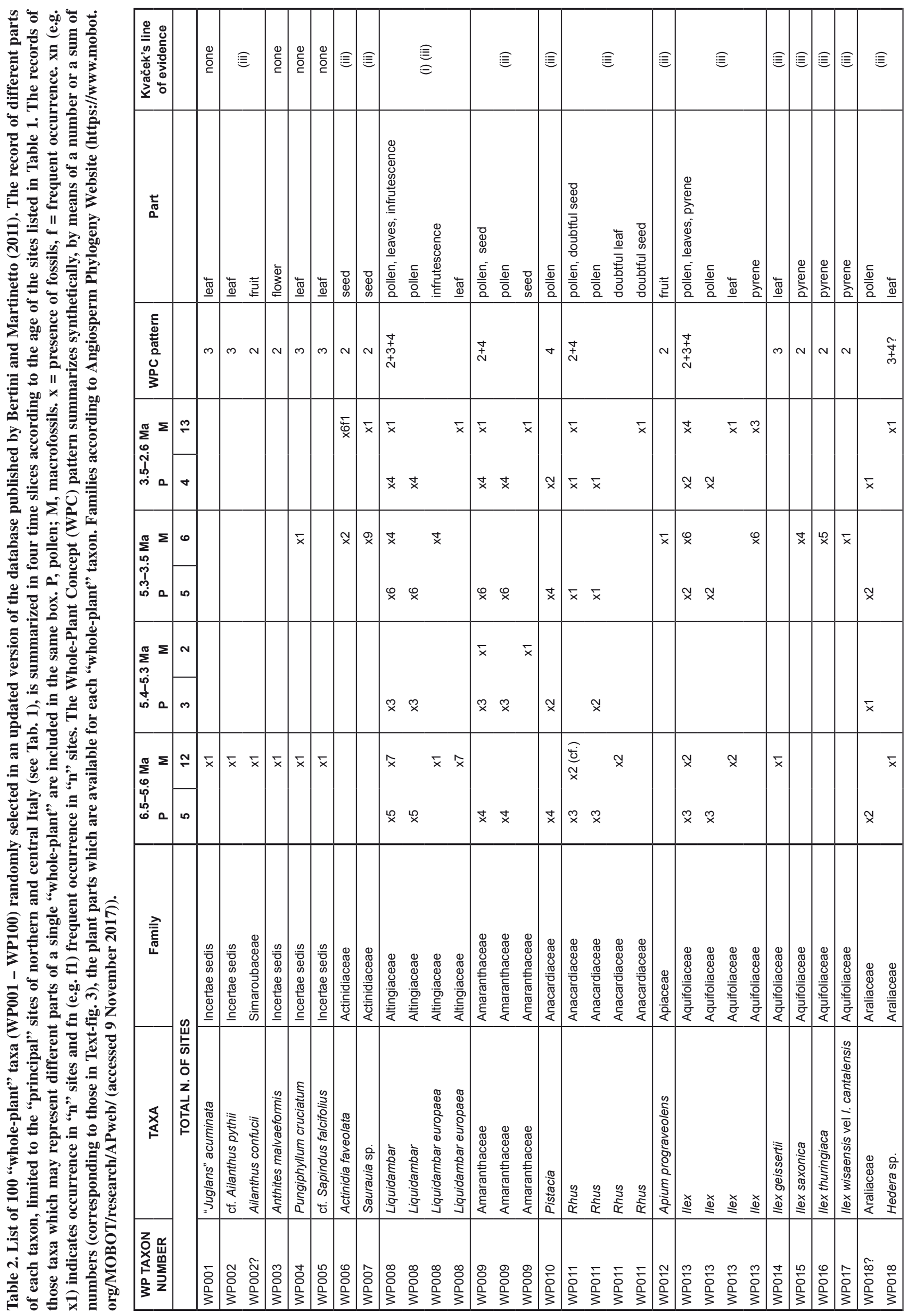




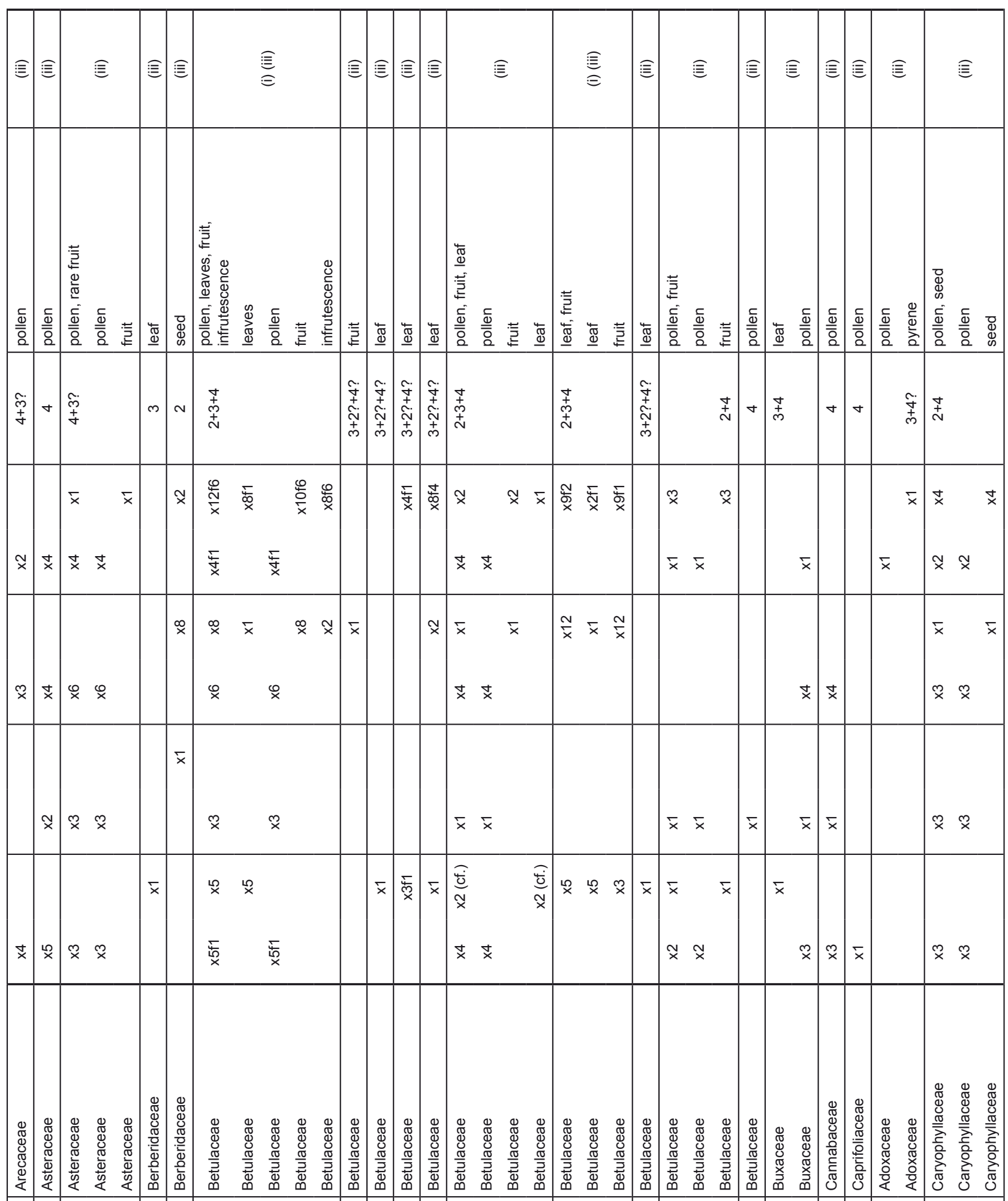

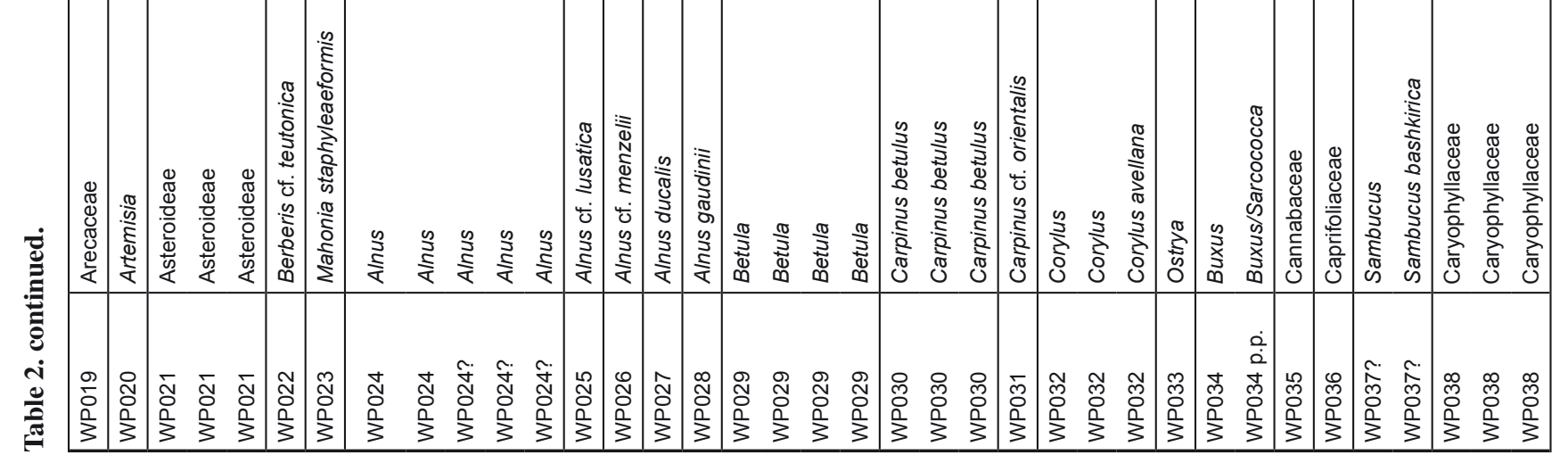




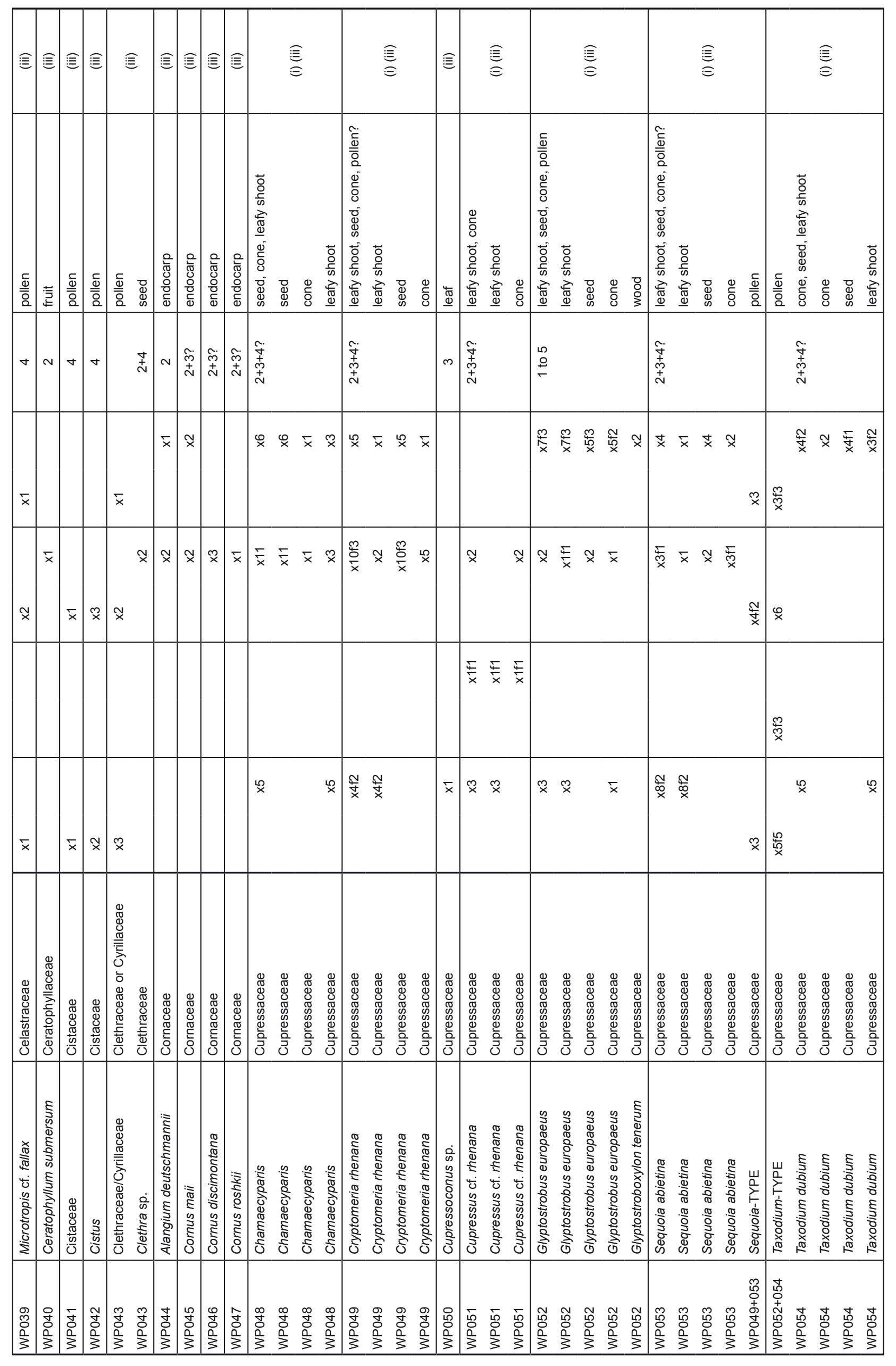




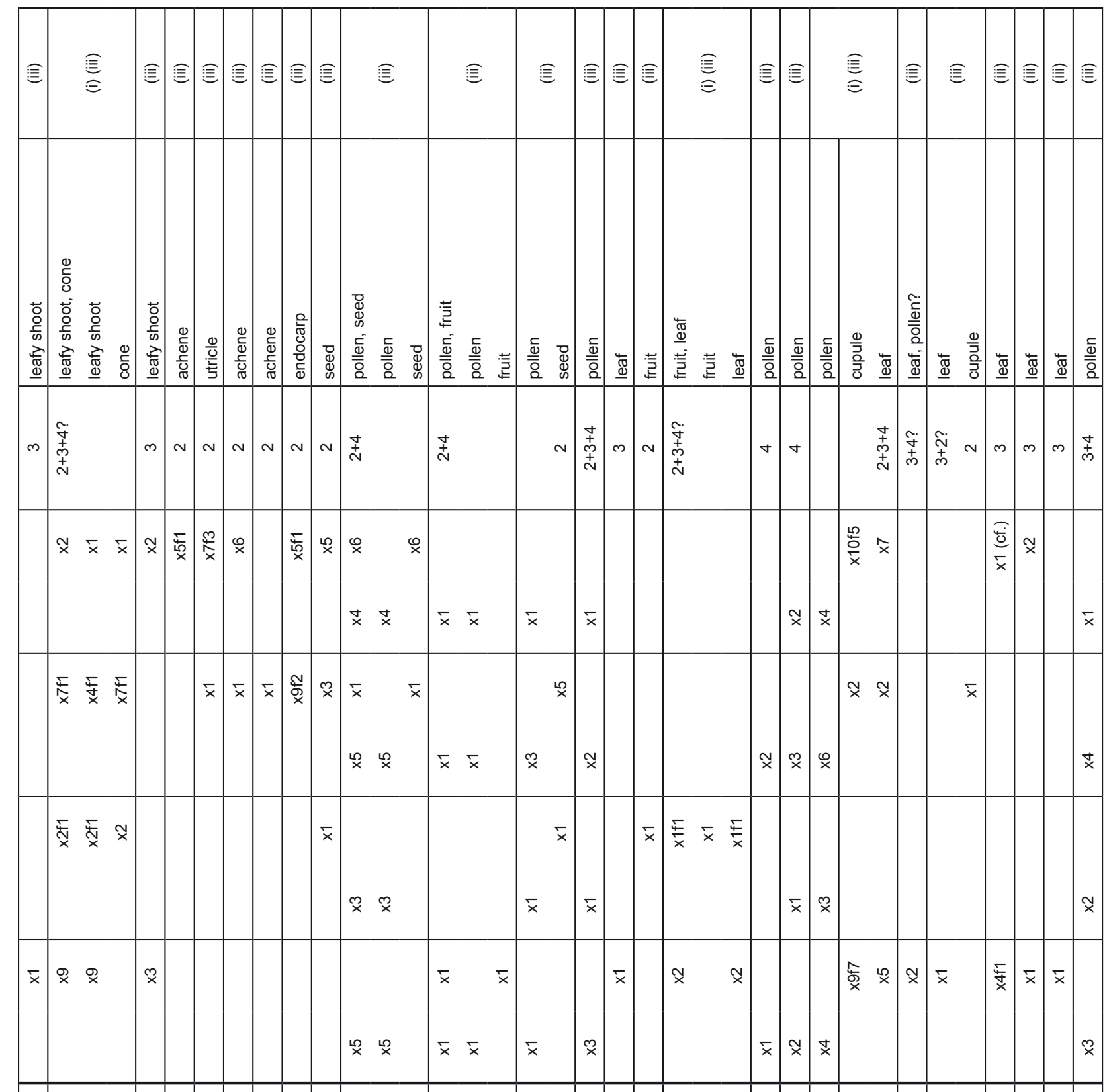

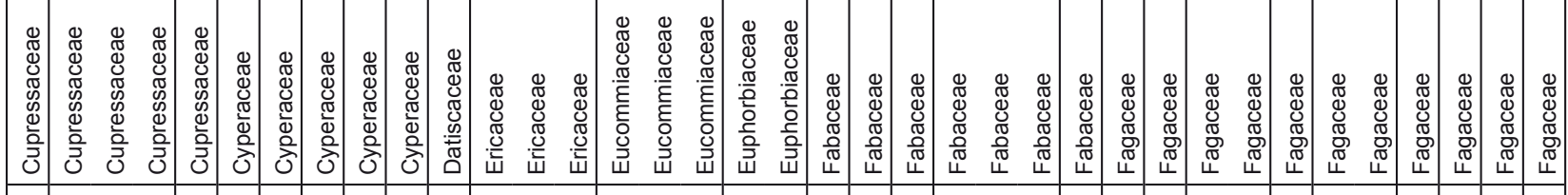

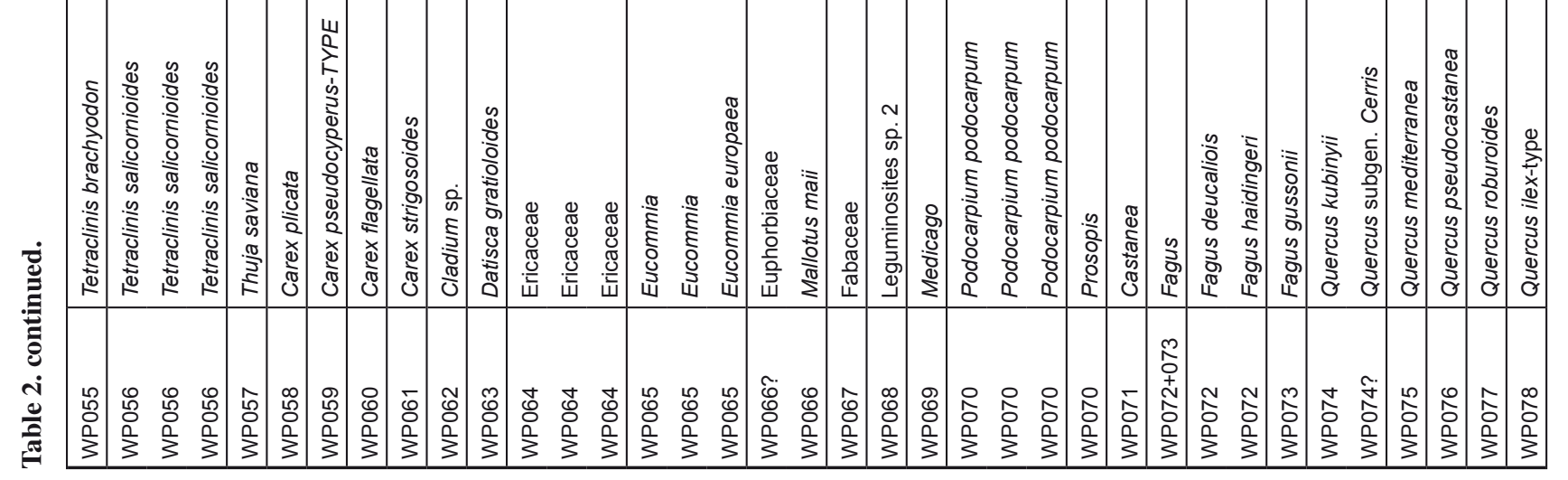




\begin{tabular}{|c|c|c|c|c|c|c|c|c|c|c|c|c|}
\hline$\stackrel{\bar{E}}{\Xi}$ & 列 & $\widehat{\equiv}$ & 巨 & $\widehat{\equiv}$ & 巨 & $\equiv$ & 巨 & 巨 & $\stackrel{\equiv}{\Xi}$ & $\stackrel{\equiv}{\Xi}$ & & $\widehat{\equiv}$ \\
\hline 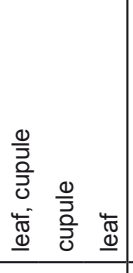 & 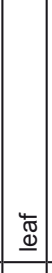 & 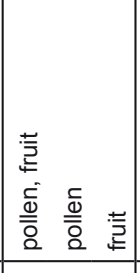 & 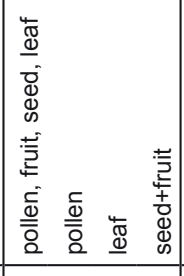 & 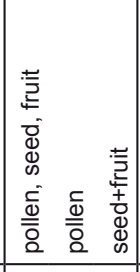 & 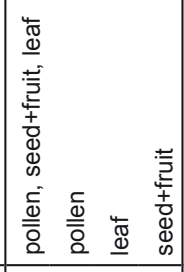 & \begin{tabular}{|c|}
$\frac{c}{\frac{c}{2}}$ \\
$\frac{\bar{c}}{2}$ \\
\end{tabular} & 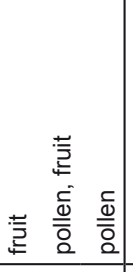 & 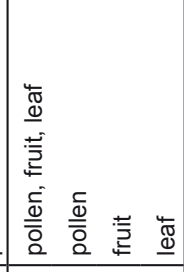 & 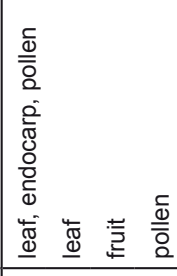 & 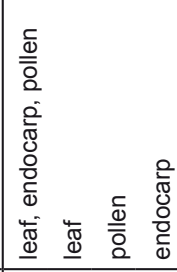 & 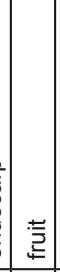 & \\
\hline$\stackrel{\infty}{\sim}$ & $m$ & $\stackrel{+}{\stackrel{+}{\sim}}$ & 萳 & $\stackrel{+}{\sim}$ & $\begin{array}{l}\stackrel{+}{+} \\
\stackrel{+}{+} \\
\stackrel{N}{N}\end{array}$ & $\nabla$ & $\stackrel{+}{\sim}$ & $\begin{array}{l}+ \\
+ \\
+ \\
\sim \\
\sim\end{array}$ & $\begin{array}{l}+ \\
+ \\
⿱ 亠 \\
\sim \\
\sim\end{array}$ & $\underset{\substack{++++}}{\sim}$ & & o \\
\hline$\tilde{x} \approx \tilde{x} \tilde{x}$ & & $\tilde{x} \approx$ & $\begin{array}{lll}\dot{x} & \bar{x} & \mathscr{x} \\
& & \end{array}$ & $\bar{x} \bar{x}$ & 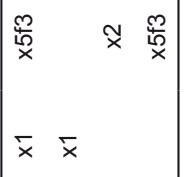 & $\bar{x}$ & $\bar{x}$ & $\mid \begin{array}{llll}\mathscr{x} & & \widetilde{x} & \bar{x} \\
\dot{x} & \mathbb{x} & & \end{array}$ & $\begin{array}{llll}\bar{x} & \bar{x} & \bar{x} & \\
& & \\
\widetilde{x} & & & \widetilde{x}\end{array}$ & 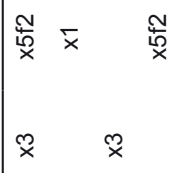 & & \\
\hline \begin{tabular}{lll}
$\frac{m}{0}$ & $\frac{m}{0}$ & $\overline{0}$ \\
\hdashline & & $x$
\end{tabular} & & 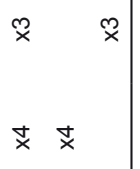 & $\begin{array}{lll}\stackrel{\infty}{x} & \stackrel{\infty}{\times} \\
\approx & \approx & \end{array}$ & $\mid \begin{array}{ll}\tilde{x} & \tilde{x} \\
\tilde{x} & \tilde{x}\end{array}$ & $\bar{x} \bar{x}$ & $\approx$ & $\bar{x} \bar{x}$ & 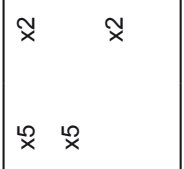 & 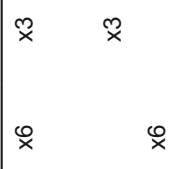 & 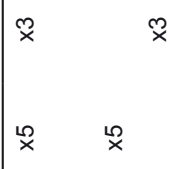 & $\bar{x}$ & \\
\hline & & $\bar{x} \bar{x}$ & $\tilde{x} \tilde{x}$ & $\bar{x} \bar{x}$ & $\bar{x} \bar{x}$ & & & $\tilde{x})$ & 怘 & $\widetilde{x}$ & & \\
\hline $\begin{array}{ll}\varnothing & \varnothing\end{array}$ & $\widetilde{x}$ & $\ddot{x} \tilde{x}$ & $\begin{array}{l}\bar{x} \bar{x} \\
\approx \tilde{x}\end{array}$ & & $\begin{array}{l}\overline{\bar{E}} \frac{\bar{\theta}}{\bar{x}} \\
\bar{x} \bar{x}\end{array}$ & $\bar{x}$ & $\approx \bar{x}$ & 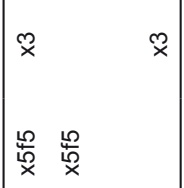 & 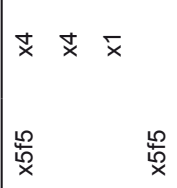 & 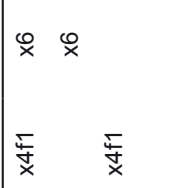 & & $\bar{x}$ \\
\hline 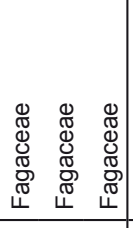 & 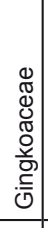 & 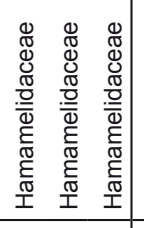 & 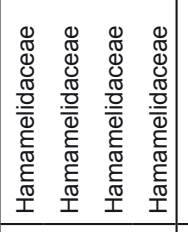 & 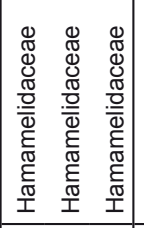 & 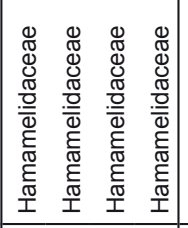 & 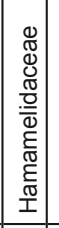 & 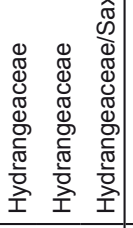 & 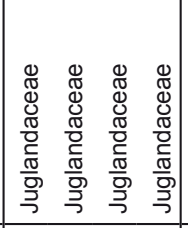 & 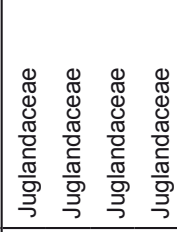 & 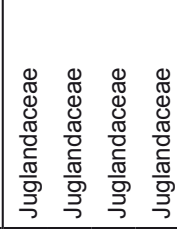 & 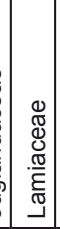 & 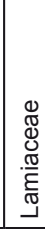 \\
\hline 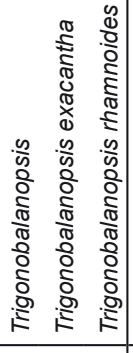 & 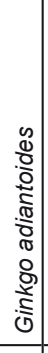 & 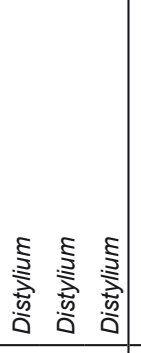 & 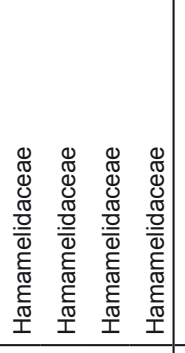 & 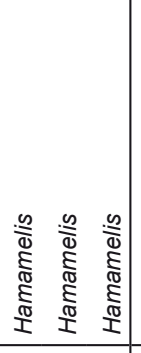 & $\begin{array}{ccccc} & & \\
0 \\
0\end{array}$ & 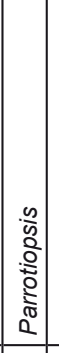 & 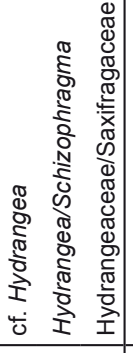 & 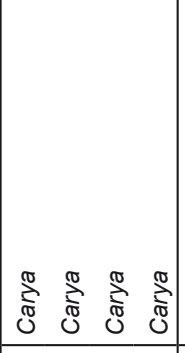 & 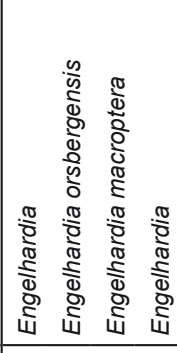 & 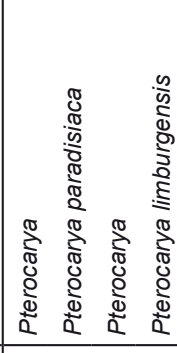 & 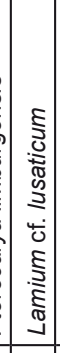 & 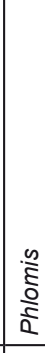 \\
\hline $\begin{array}{lll}0 & 9 & 0 \\
0 & 0 & 0 \\
0 & 0 & 0 \\
3 & 0 & 0 \\
3\end{array}$ & $\begin{array}{l}0 \\
0 \\
0 \\
0 \\
3\end{array}$ & 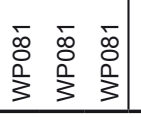 & 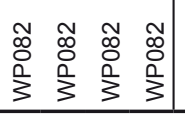 & $\begin{array}{lll}\infty & \infty & 0 \\
0 & 0 & 0 \\
0 & 0 & 0 \\
3 & 0 & 0 \\
3 & 0 \\
3\end{array}$ & 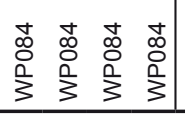 & \begin{tabular}{|l|} 
\\
0 \\
0 \\
0 \\
3 \\
\end{tabular} & $\begin{array}{llll}0 & 0 & 0 \\
0 & 0 & 0 \\
0 & 0 & 0 \\
3 & 0 & 0 \\
3 & 0 \\
3\end{array}$ & 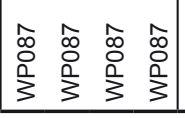 & 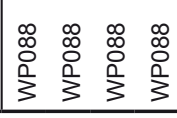 & 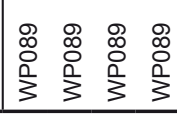 & $\begin{array}{l}0 \\
0 \\
0 \\
\vdots \\
3\end{array}$ & s. \\
\hline
\end{tabular}




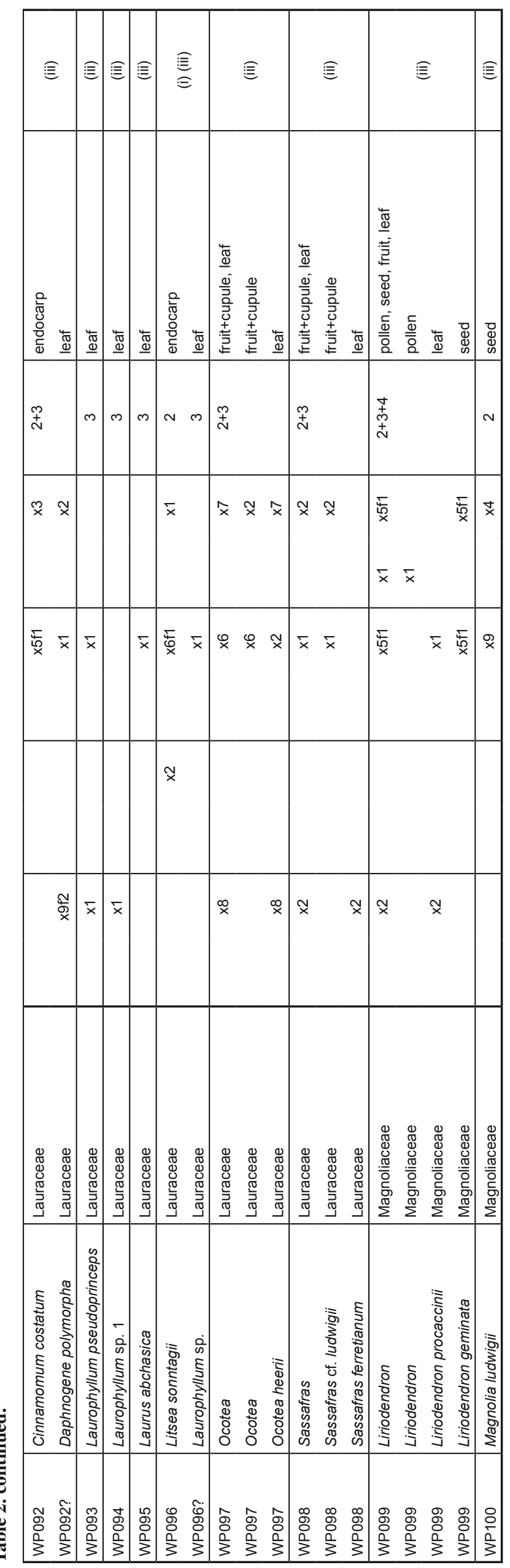

Table 3. Quantitative evidence of the combination of plant parts available for 100 "whole-plant" taxa (WP001 - WP100) from the Messinian - Piacenzian sites of northern and central Italy. See Table 2 for explanation of Whole-Plant Concept (WPC) pattern.

\begin{tabular}{|c|c|c|c|}
\hline Combinations & $\begin{array}{c}\text { Nr. taxa } \\
\text { (species?) }\end{array}$ & Notes & Percentages \\
\hline $\begin{array}{l}1 \text { to } 5 \\
2+3+4\end{array}$ & $\begin{array}{c}1 \\
13\end{array}$ & plus 14 dubious & $\begin{array}{c}14 \% \text { taxa } \\
\text { (represented by } \\
\text { more than two } \\
\text { parts) }\end{array}$ \\
\hline $\begin{array}{l}2+3 \\
3+4 \\
2+4\end{array}$ & $\begin{array}{c}11 \\
2 \\
10\end{array}$ & $\begin{array}{l}\text { plus } 4 \text { dubious } \\
\text { plus } 5 \text { dubious }\end{array}$ & $\begin{array}{c}23 \% \text { taxa } \\
\text { (represented by } \\
\text { two parts) }\end{array}$ \\
\hline $\begin{array}{c}2 \text { (carpological) } \\
3 \text { (leaf) } \\
4 \text { (pollen) }\end{array}$ & $\begin{array}{l}25 \\
25 \\
13\end{array}$ & & $\begin{array}{c}63 \% \text { taxa } \\
\text { (represented by } \\
\text { only one part) }\end{array}$ \\
\hline
\end{tabular}

Mate ria l. The CENOFITA database (Martinetto and Vassio 2010, Martinetto 2015) contains seed records from 13 Italian localities, spanning from Zanclean to Gelasian; most localities provided only one or a few seeds of $A$. faveolata (Text-fig. 4a), whereas a richer assemblage (104 specimens) was collected from the Fossil Forest of the Stura di Lanzo River (Martinetto et al. 2007a).

Remarks. The Actinidia faveolata whole-plant is documented only by seeds. Absence of leaf, stem and pollen materials (Text-fig. 4b-d) of Actinidia in the fossil record does not permit an independent reconstruction of the ancient seed-producing plant. A hypothetical whole-plant reconstruction can be formulated on the basis of the similarity of the seeds of $A$. faveolata to those of the modern species $A$. arguta (Text-fig. 4e) and A. kolomikta (Kirchheimer 1957, Łańcucka-Środoniowa 1966). Therefore, the whole-plant of the European late Cenozoic can be reconstructed thanks to our knowledge of these modern East Asian plants (line of evidence ISA) and their phylogenetic framework (Chat et al. 2004). Actinidia is a phylogenetically isolated genus, therefore we can reconstruct the habitus of $A$. faveolata simply by analyzing the habitus of the related living members of this genus. A. arguta and A. kolomikta are regarded as basal species in the phylogenetic tree of Actinidia (Chat et al. 2004), and these are woody climbers of medium to large height, with spirally arranged deciduous ovate leaves, bearing clusters of centimetre-sized berries containing numerous seeds (Text-fig. 4f). Therefore, also the fossil $A$. faveolata, with very similar seeds, can be reconstructed as a plant with such features.

\section{Family Eucommiaceae EngLer, 1907}

\section{Genus Eucommia Oliver, 1890}

Eucommia europaea whole-plant

Eucommia europaea MÄDLER (fruit); Eucommia (pollen); possibly also cf. Eucommia (wood)

P1. 1, Figs 1-4

Material. Fruits from Monte Tondo, Messinian (2 specimens). We also considered an almost complete fruit 

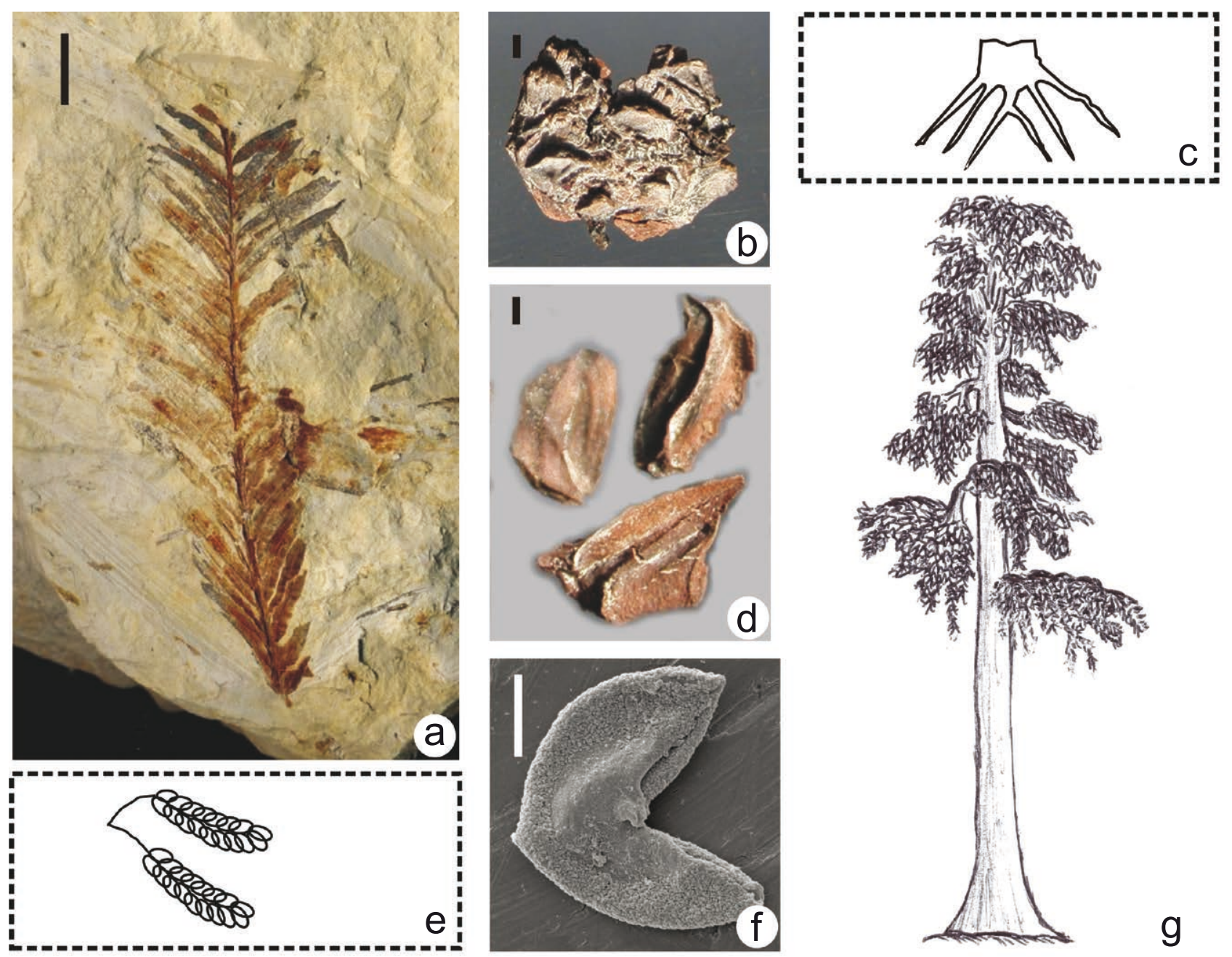

Text-fig. 6. Identity plate of the Taxodium dubium whole-plant. a) foliage shoot, Castelnuovo Don Bosco, Piacenzian (from Bertini and Martinetto 2014). b) cone from Villafranca d'Asti - RDB Quarry, Piacenzian. c) remains of woody axes missing. d) seeds from the same site. e) remains of amenta missing. f) Taxodium-type pollen from Rio Maior (photo by M. Vieira, Portugal: Vieira et al. 2018), Piacenzian. g) reconstruction of the Taxodium dubium whole-plant based on line of evidence ISA (drawing L. Macaluso). Scale bar $10 \mathrm{~mm}$ for $\mathrm{a}, 1 \mathrm{~mm}$ for $b, d$ and $20 \mu \mathrm{m}$ for $\mathrm{f}$.

specimen from the Calabrian site Stirone-Laurano (see $\mathrm{SP}$ in Text-fig. 1). Even though other Pleistocene records (Martinetto 2015) are not detailed here, it should be mentioned that the recent report by Martinetto et al. (2015) includes an early Gelasian occurrence from the ArdaCastell'Arquato-AD3 locality (see CQ in Text-fig. 1), whose age was estimated to be around 2.5-2.4 Ma. However, this age was challenged by Crippa et al. (2016), who assigned the deposits, just above the plant-bearing layer, to the base of the Calabrian (i.e. around 1.8 Ma), whereas Monesi et al. (2016) classified this interval as "not interpreted" from a chronostratigraphic point of view. Pollen of Eucommia is rare and found in just a few Messinian - Piacenzian sites.

Remarks. The occurrence of Eucommia in the Neogene of Italy was mentioned by Günther and Gregor (1990) for the Piacenzian locality Santa Barbara, but without description and illustration of the possible fruit specimen (record to be verified). Recently, two fossil fruits (not reported in Martinetto 2015, who described Pleistocene specimens, nor in Teodoridis et al. 2015b) were detected in the Messinian deposit of Monte Tondo. Despite their incompleteness, the winged fruits can be definitely assigned to Eucommia because they show an apparent reticulate pattern of veins and latex filaments over the seed, and a medial vascular strand separating the fertile carpel and the vestigial infertile carpel (Call and Dilcher 1997). Only a single almost complete fossil fruit (Pl. 1, Fig. 4) was found in Italy so far, and it originates from the late early Pleistocene deposits of Stirone-Laurano.

All the determinable fruit specimens of the late Cenozoic of Europe have been recognized as very similar to Eucommia ulmoides (Tralau 1963, Call and Dilcher 1997, Kvaček et al. 2008, Manchester et al. 2009), but they were often assigned to a fossil-species named Eucommia europaea MäDLER, whose actual distinction from the living biological species Eucommia ulmoides has even been questioned (Tralau 1963). However, the fruits of E. europaea are described as being larger (Manchester et al. 2009) and the possible associated leaves as more entire-margined (Kvaček et al. 2008) in comparison to those in the single living species. Four other fossil-species names have been applied to Cenozoic fossil fruits (E. palaeoulmoides BAJK. also to leaves) from Eastern 
Europe and Siberia (Zhilin 1974). Since there is no definite evidence for the occurrence of more than one species of Eucommia in the late Cenozoic of Central and Western Europe, and all the available fruit material (Neogene and Pleistocene) from Italy conforms to the characters of $E$. europaea, we assign it to this fossil-species.

The picture of this possibly extinct "Eucommia europaea whole-plant" is supported by the rare Neogene pollen grains identified as "Eucommia" (Bertoldi and Martinetto 1995, Bertini 2010). These occur more abundantly in the Italian early Pleistocene (Ravazzi 2003: 99), where also fossil woods of cf. Eucommia have been reported (Pini et al. 2014), although no leaf remains were so far reported from Italian sites. The various fossil remains are useful for the reconstruction of the ancient whole-plant, but in reality the strong similarity of the fossil and corresponding modern parts suggests a close systematic affinity of E. europaea to the modern plant E. ulmoides (Ying et al. 1993), whose aspect can be assumed as a model for the "Eucommia europaea whole-plant" (line of evidence ISA). Considering that the family Eucommiaceae is very isolated within the clades of Garryales (Stull et al. 2015), the only possible habitus is the one of the single living species of this family: trees with spirally arranged deciduous elliptic leaves and samaroid fruits.

\section{Family Juglandaceae DC. ex Perleb, 1818}

\section{Genus Engelhardia Leschenaut ex Blume, 1826}

Engelhardia macroptera whole-plant

Engelhardia (sect. Palaeocarya) macroptera (BRONGNIART) UNGER (fruit); Engelhardia

orsbergensis (P.WESSEL et C.O.WEBER) JäHNICHEN, MAI et H.WALther (leaf); Engelhardia (pollen)

Pl. 1, Figs 8-11

Material. Fruit bracts from the Messinian of Monte Tondo (2 specimens) and Tossignano (5), from the Pliocene of Meleto (1) and Valle del Salto (1). Several fruits without bracts from two Zanclean localities: Ca' Viettone and Sento. Leaflets from the pre-evaporitic Messinian of Pollenzo (Bertini and Martinetto 2014: 1 specimen, lost), Palena (Teodoridis et al. 2015a: 1 specimen), the Damarco bed of the evaporitic Messinian of Govone (3 specimens, Palaeontological Museum of Astigiano and Monferrato). Pollen grains of Engelhardia are frequent in several Messinian and Zanclean sites, but less abundant in the Piacenzian (Bertoldi 1988, 1996, Bertoldi et al. 1994, Bertoldi and Martinetto 1995, Bertini 2010 and references therein).

Remarks. The attribution to the living genus Engelhardia of rare fruits, fruit-bracts, leaves, and more frequently pollen, found scattered in several Italian sites of different ages, is the basis for the formulation of an Engelhardia macroptera Whole-Plant Concept for the Neogene of Italy, according to the line of evidence ISA. The fruits are small thin walled nuts, represented in the sandy sediments of a few Pliocene sites by just 1 to 3 specimens, isolated from any other Engelhardia remains, being more abundant only at the Ca' Viettone site (Martinetto and Vassio 2010, Martinetto et al. 2018). In fine-grained sediments the nuts are sometimes accompanied by characteristic involucres consisting of three apical triveined lobes and one basal, opposite small lobe enveloping the nut (3 to 5 $\mathrm{mm}$ in diameter). In Italy the involucres have been reported from Messinian (Bertini and Martinetto 2008) and Pliocene sites (Fischer and Butzmann 2000), as well as from Valle del Salto, a site of uncertain Pliocene or Pleistocene age (Chiarini et al. 2009). Similar fruits in the European Oligocene and Miocene are accompanied by leaflets with finely serrate margins and a sessile asymmetrical base, which are assigned to Engelhardia orsbergensis (Kvaček 2007, Teodoridis et al. 2015b). In Italy only a few leaflet specimens were reported, often with uncertain identification (Bertini and Martinetto 2014, Teodoridis et al. 2015a, Cimino et al. 2016). In this paper we confirm the occurrence of leaflets in the Damarco bed of Govone (Cimino et al. 2016) because of two new specimens that show diagnostic characters pointing to Engelhardia orsbergensis. Pollen grains identified as "Engelhardia" (Bertini 2010, Magri et al. 2017 and references therein) or "Engelhardia/Platycaryatype" (Bertoldi 1988, 1996, Bertoldi et al. 1994, Bertoldi and Martinetto 1995) can be tentatively referred to the same whole-plant on the basis of the line of evidence ISA.

Because all the members of the Engelhardia phylogenetic clade (Zhang et al. 2013), including Alfaroa and Oreomummea, are trees of medium to large height, with opposite deciduous imparipinnate leaves and catkins of centimetre-sized nut-bearing bracts, the fossil Engelhardia macroptera whole-plant would also share this kind of habitus.

\section{Family Simaroubaceae DC., 1811}

\section{Genus Ailanthus Desfontaines, 1786}

\section{Ailanthus confucii whole-plant}

Ailanthus confucii UNGER (fruit); possibly also cf. Ailanthus pythii (Unger) Kovar-Eder et KVAČEK (leaf)

$$
\text { Pl. 1, Figs 5-7 }
$$

Material. Leaflets of cf. Ailanthus pythii from Monte Tondo (14 specimens) and Tossignano (2 specimens) (Teodoridis et al. 2015b). A single fruit of Ailanthus confucii from Monte Castellaro. All findings from Messinian sites dated within the time range 6.5-5.6 Ma.

R e m a rks. A single fruit of Messinian age, reported for the first time in this paper, testifies to the occurrence of the fossil-species Ailanthus confucii in the Cenozoic of Italy. It is $33 \mathrm{~mm}$ long, has a v-shaped acute stylar scar in the middle of the seed, and an apparent ventral vein (see $\mathrm{Su}$ et al. 2013 for terminology). The distinction between fruits of A. confucii and those of the modern species A. altissima is not straightforward, the single differential character seems to be the acute versus obtuse fruit base ( $\mathrm{Su}$ et al. 2013); additionally, the deeper and acute stylar scar in $A$. confucii should be evaluated as a character not present in A. altissima. Leaves from another Messinian site, identified as "cf. Ailanthus pythii" (Teodoridis et al. 2015b), may doubtfully be referred to the same ancient whole-plant because they are comparable with the type material from the middle Miocene site Parschlug (Kovar-Eder et al. 2004). However, the assignment may not be without problems as the leaves are 
also similar to "Sapindus" falcifolius (A.Braun) A.Braun (Teodoridis et al. 2015b). Leaflets of the same morphology were described as Ailanthus mecsekensis by Hably (2001) from a fossiliferous layer at Magyaregregy in Hungary, with a mass occurrence of fruits assigned to Ailanthus confucii. The fruit from Monte Castellaro is smaller than the largest Hungarian fossil fruits, but it fits within the range of size variation reported by Corbett and Manchester (2004) for this fossil-species which had a circumboreal distribution from the Eocene to the Miocene.

All members of the Ailanthus phylogenetic clade (Clayton et al. 2009) are trees of medium to large height, with opposite deciduous imparipinnate leaves, bearing clusters of centimetre-sized samaroid fruits. Because the genus Ailanthus is a significantly isolated clade, distinct from the sister taxa, the fossil Ailanthus confucii whole-plant was also certainly a tree with similar features (line of evidence ISA), and most probably shared several characteristics with the modern plant Ailanthus altissima (Kowarik and Säumel 2007).

\section{Discussion and conclusions}

The updated Bertini and Martinetto (2011) database which we analysed included fossil records of several tens of taxa from northern and central Italy, represented by different organs. The difficulty with applying the Whole-Plant Concept to the fossil flora of a broad area is emphasised by the relevant occurrence (63\%) of taxa represented by a single type of plant part. Moreover, the taxa represented by three kinds of organs were relatively rare, and only one taxon showed an almost complete combination of parts: the "Glyptostrobus europaeus whole-plant" (Vassio et al. 2008).

The main source of uncertainty was the different degree of taxonomic resolution: carpological remains, leaves and woods were often assigned to definite species or fossilspecies, but pollen was mostly identified at genus (or family) level. In fact, pollen morphology often does not provide the same degree of systematic resolution as macroremains, even when a "formal" pollen nomenclature is applied (e.g. Stuchlik 2001). In addition, for several leaf and carpological remains the assignment to definite species has not yet been assessed (e.g. Alnus, Apiaceae, Caryophyllaceae, Chenopodiaceae, Ericaceae, etc.) or it is even potentially impossible.

In conclusion, the Messinian - Piacenzian macrofossil and pollen records of north and central Italy provided a useful database for a quantitative application of the Whole-Plant Concept. The interpretation of several isolated fossilized plant parts allowed us to hypothesize combinations of pollen, foliage and reproductive structures under collective whole-plant taxa. A random selection of 100 taxa allowed us to analyse quantitatively the fossil flora from the viewpoint of the available assemblage of parts for each ancient wholeplant. Nearly $2 / 3$ of the hypothetical whole-plant taxa (63\%) turned out to be represented by a single part (reproductive structure or leaf), and only $14 \%$ were represented by more than two parts. We do not know to what extent the results obtained in the particular situation we studied could be extended to the palaeofloras from other time slices and sites worldwide. However our results suggest that the whole- plant taxa reconstructed by assembling several fossil parts may represent a small proportion of the palaeobiodiversity of terrestrial plants.

\section{Acknowledgements}

This paper is dedicated to Zlatko Kvaček on his $80^{\text {th }}$ birthday, and we would like to thank him not only for the long term friendly support of our studies, but also for the help provided in the identification of the leaf material used for our analyses (in particular Engelhardia). Our special thanks to Adele Bertini, for general collaboration in the analysis of the pollen record and for the photographic documentation of Engelhardia pollen; to Angelo Orzi and Marco Sami for collaboration in the preparation and photographic documentation of the specimens shown in P1. 1. Many thanks also to Erio Camporesi, who alerted us to the Ailanthus fruit from Monte Castellaro; to the Museo Civico di Scienze Naturali of Faenza and to the Museo Paleontologico "L. Sorbini" of Fiorenzuola di Focara, for the support in analyzing their collections. We are thankful to Angela Bruch and Vasilis Teodoridis for their substantial contribution which improved the manuscript. We also thank Nela Doláková, Marianna Kováčová and Manuel Vieira for providing useful pollen photographs and Steve Manchester for useful suggestions and for proofreading the text. This work was financially supported by "Fondi di Ateneo dell'Università di Torino" (MARE_RILO_16_01) (20152016).

\section{References}

Allason, B., Carraro, F., Ghibaudo, G., Paganelli, A., Ricci, B. (1981): Prove palinologiche dell'età pleistocenica inferiore di depositi "villafranchiani" in Piemonte [Palynological proves of the Early Pleistocene age for "Villafranchian" deposits in Piedmont]. - Geografia Fisica e Dinamica Quaternaria, 4: 39-47.

Bartolucci, F., Peruzzi, L., Galasso, G., Albano, A., Alessandrini, A., Ardenghi, N. M. G., Astuti, G., Bacchetta, G., Ballelli, S., Banfi, E., Barberis, G., Bernardo, L., Bouvet, D., Bovio, M., Cecchi, L., Di Pietro, R., Domina, G., Fascetti, S., Fenu, G., Festi, F., Foggi, B., Gallo, L., Gubellini, L., Gottschlich, G., Iamonico, D., Iberite, M., Jinénez-Mejías, P., Lattanzi, E., Martinetto, E., Masin, R. R., Medagli, P., Passalacqua, N. G., Peccenini, S., Pennesi, R., Pierini, B., Poldini, L., Prosser, F., Raimondo, F. M., Marchetti, D., Roma-Marzio, F., Rosati, L., Santangelo, A., Scoppola, A., Scortegagna, A., Selvaggi, A., Selvi, F., Soldano, A., Stinca, A., Wagensommer, R. P., Wilhalm, T., Conti, F., Barberis, G. (2018): An updated checklist of the vascular flora native to Italy. - Plant Biosystems - An International Journal Dealing with all Aspects of Plant Biology, 152(2): 179-303. https://doi.org/10.1080/11263504.2017.1419996

Basilici, G., Martinetto, E., Pavia, G., Violanti, D. (1997): Paleoenvironmental evolution in the Pliocene marine-coastal succession of Val Chiusella (Ivrea, NW Italy). - Bollettino della Società Paleontologica Italiana, 36(1-2): 23-52. 
Benvenuti, M., Bertini, A., Conti, C., Dominici, S. (2007): Integrated analyses of litho- and biofacies in a Pliocene cyclothemic, alluvial to shallow marine succession (Tuscany, Italy). - Geobios, 40(2): 143-158.

https://doi.org/10.1016/j.geobios.2006.08.001

Berger, W. (1958): Untersuchungen an der obermiozänen (sarmatischen) Flora von Gabbro (Monti Livornesi) in der Toskana. - Palaeontographica Italica, 51: 1-96.

Bertini, A. (1992): Palinologia ed aspetti ambientali del versante adriatico dell'Appennino centro-settentrionale durante il Messiniano e lo Zancleano [Palynology and palaeoenvironmental aspects of the Adriatic slope of the central-northern Apennine during Messinian and Zanclean]; Ph.D. thesis. - MS, Dipartimento di Scienze della Terra, Università degli Studi di Firenze, Florence, Italy, $88 \mathrm{pp}$. (in Italian) (copy in library of the Department of Earth Sciences, University of Florence)

Bertini, A. (1994a): Palynological investigations on Upper Neogene and Lower Pleistocene sections in central and northern Italy. - Memorie della Società Geologica Italiana, 48: 431-443.

Bertini, A. (1994b): Messinian-Zanclean vegetation and climate in North-Central Italy. - Historical Biology, 9: 3-10. https://doi.org/10.1080/10292389409380483

Bertini, A. (2001): Pliocene climatic cycles and altitudinal forest development from 2.7 Ma in the northern Apennines (Italy): evidences from the pollen record of the Stirone section (5.1 to 2.2 Ma). - Geobios, 34: 253-265. https://doi.org/10.1016/S0016-6995(01)80074-7

Bertini, A. (2002): Palynological evidence of upper Neogene environments in Italy. - Acta Universitatis Carolinae, Geologica, 46: 15-25.

Bertini, A. (2006): The Northern Apennines palynological record as a contribute for the reconstruction of the Messinian palaeoenvironments. - Sedimentary Geology, 188(189): 235-258. https://doi.org/10.1016/j.sedgeo.2006.03.007

Bertini, A. (2010): Pliocene to Pleistocene palynoflora and vegetation in Italy: state of the art. - Quaternary International, 225: 5-24. https://doi.org/10.1016/j.quaint.2010.04.025

Bertini, A., Martinetto, E. (2008): Messinian to Zanclean vegetation and climate of Northern and Central Italy. Bollettino della Società Paleontologica Italiana, 47(2): 105-121.

Bertini, A., Martinetto, E. (2011): Reconstruction of vegetation transects for the Messinian Piacenzian of Italy by means of comparative analysis of pollen, leaf and carpological records. - Palaeogeography, Palaeoclimatology, Palaeoecology, 304(3): 230-246.

https://doi.org/10.1016/j.palaeo.2010.09.005

Bertini, A., Martinetto, E. (2014): The Neogene flora of the Italian peninsula and Sicily. - In: Kustatscher, E., Roghi, G., Bertini, A., Miola, A (eds), Palaeobotany of Italy. Naturmuseum Sudtirol, Bolzano, pp. 248-279.

Bertoldi, R. (1988): Una sequenza palinologica di età Rusciniana nei sedimenti lacustri basali del bacino di AullaOlivola (Val di Magra) [A pollen sequence of Ruscinian age in the lacustrine sediments at the bottom of the Aulla-Olivola basin (Val di Magra)]. - Rivista Italiana di Paleontologia e Stratigrafia, 94(1): 105-138. (in Italian)
Bertoldi, R. (1996): Pollini. Il Complesso Inferiore [Pollen. The Lower Complex]. - In: Carraro, F. (ed.), Revisione del Villafranchiano nell'area-tipo di Villafranca d'Asti [Revision of the Villafranchian in the type-area of Villafranca d'Asti]. - Il Quaternario, 9: 79-85. (in Italian)

Bertoldi, R., Binotti, A., Castello, F. (1994): Reevesia and Itea in the pollen flora of the Upper Neogene continental deposit at Sarzana (lower Magra valley, Northern Italy). - Review of Palaeobotany and Palynology, 80: 159-172. https://doi.org/10.1016/0034-6667(94)90100-7

Bertoldi, R., Martinetto, E. (1995): Ricerche paleobotaniche (palinologiche e paleocarpologiche) sulla successione "villafranchiana" del Rio Ca' Viettone [Palaeobotanical (palynological and palaeocarpological) researches on the "Villafranchian" succession of the Ca' Viettone brook]. Il Quaternario, 8(2): 403-422. (in Italian)

Biondi, E. (1982): Taxodioxylon gypsaceum (GöPPERT) KRÄUSEL, legno fossile rinvenuto nel Miocene dell'Italia centrale [Taxodioxylon gypsaceum (GöPPERT) KRÄUSEL, fossil wood found in the Miocene of central Italy]. - Giornale Botanico Italiano, 116: 227-233. (in Italian) https://doi.org/10.1080/11263508209428069

Biondi, E., Koeniguer, J.-C., Privé-Gill, C. (1985): Bois fossiles et végétations arborescentes des régions méditerranéennes durant le Tertiaire. - Giornale Botanico Italiano, 119: 167-196. https://doi.org/10.1080/11263508509428014

Bomfleur, B., Decombeix, A.-L., Escapa, I. H., Schwendemann, A. B., Axsmith, B. (2013) : Whole-plant concept and environment reconstruction of a Telemachus conifer (Voltziales) from the Triassic of Antarctica. - International Journal of Plant Sciences, 174(3): 425-444. https://doi.org/10.1086/668686

Bonci, M. C., Vannucci, G., Tacchino, S., Piazza, M. (2011): Oligocene fossil leaves of the Perrando Collection: history, preservation, and paleoclimatic meaning. - Bollettino della Società Paleontologica Italiana, 50(3): 145-164.

Brambilla, G. (1984): I vegetali fossili delle argille grigie plioceniche del T. Tornago (BG) nelle collezioni del Museo Civico "E. Caffi" di Bergamo [Fossil plants of the Pliocene gray clays of the Tornago stream (province of Bergamo) in the collections of the "E. Caffi" Museum of Bergamo]. - Rivista del Museo di Scienze Naturali di Bergamo, 8: 3-16. (in Italian)

Brambilla, G. (1992a): Prime considerazioni cronologico-ambientali sulle filliti del Miocene superiore di Portalbera (Pavia-Italia settentrionale) [First chronological-palaeoenvironmental considerations on the fossil leaves from the upper Miocene of Portalbera (PaviaNorthern Italy)]. - In: Pearce, M. (ed.), Nuove ricerche archeologiche in provincia di Pavia [New archaeological researches in the province of Pavia].. Civico Museo Archeologico di Casteggio e dell'Oltrepò Pavese, Casteggio, pp. 109-113. (in Italian)

Brambilla, G. (1992b): Le filliti plioceniche del Canton Ticino nelle collezioni del Museo Cantonale di Storia Naturale di Lugano: considerazioni sistematiche, cronologiche ed ambientali [Pliocene fossil leaves from Canton Ticino in the collections of the Cantonale Museum of Natural History of Lugano: systematical, chronological and environmental considerations]. - Bollettino della 
Società Ticinese di Scienze Naturali, 80(2): 63-95. (in Italian)

Brambilla, G., Gallo, M. (2002): Analisi stratigrafica e paleobotanica della successione messiniana di Bric Santa Margherita (Nizza Monferrato, Asti, Italia NW) [Stratigraphic and palaeobotanical analysis of the Messinian succession of Bric Santa Margherita (Nizza Monferrato, Asti, Italia NW)]. - Bollettino del Museo Regionale di Scienze Naturali, Torino, 19(1): 191-283. (in Italian)

Brambilla, G., Ronchetti, G., Vittadini Zorzoli, M. (1982): Semi e filliti delle argille messiniane (Miocene superiore) di Carbonara Scrivia (Alessandria) [Seeds and fossil leaves of the Messinian clays (upper Miocene) of Carbonara Scrivia (Alessandria)]. - Atti Istituto Botanico e del Laboratorio Crittogamico Pavia, 1: 31-40. (in Italian)

Call, V. B., Dilcher, D. L. (1997): The fossil record of Eucommia (Eucommiaceae) in North America. - American Journal of Botany, 84: 798-814. https://doi.org/10.2307/2445816

Cavallo, O., Martinetto, E. (1996): Flore plioceniche del bacino del Tanaro [Pliocene floras of the Tanaro basin]. Alba Pompeia, 17(1): 5-31. (in Italian)

Cavallo, P., Martinetto, E. (2001): Flore carpologiche del Pliocene di Castelletto Cervo (Biella) [Carpological floras of the Pliocene of Castelletto Cervo (Biella)]. - Bollettino del Museo Regionale di Scienze Naturali Torino, 18(2): 277-343. (in Italian)

Ciangherotti, A., Esu, D., Martinetto, E., Giuntelli, P. (2007): The remarkable Middle Pliocene non-marine mollusc record from Ceresole d'Alba, Piedmont, north-west Italy: biochronology, palaebiogeography and palaeoecology supported by fossil plants. - Geobios, 40: 573-587. https://doi.org/10.1016/j.geobios.2006.10.005

Chat, J., Jáuregui, B., Petit, R. J., Nadot, S. (2004): Reticulate evolution in kiwifruit (Actinidia, Actinidiaceae) identified by comparing their maternal and paternal phylogenies. - American Journal of Botany, 91(5): 736-747. https://doi.org/10.3732/ajb.91.5.736

Chiarini, E., Giardini, M., Mattei, M., Papasodaro, F., Porreca, M., Sadori, L. (2009): Plio-Quaternary geological evolution of the high Salto river valley (central Italy): the Marano de' Marsi unit. - Il Quaternario, 22(2): 325-344.

Cimino, D., Chiantore, O., Martinetto, E., Damarco, P., Poli, T. (2016): Leaf compressions from the Late Miocene sections of NW Italy: research on an efficient, easy and quick consolidation treatment. - Fossil Imprint, 72(3-4): 172-182. https://doi.org/10.14446/FI.2016.172

Clayton, J. W., Soltis, P. S., Soltis, D. E. (2009): Recent long-distance dispersal overshadows ancient biogeographical patterns in a pantropical angiosperm family (Simaroubaceae, Sapindales). - Systematic Biology, 58(4): 395-410.

https://doi.org/10.1093/sysbio/syp041

Cleal, C. J., Thomas, B. A. (2010): Botanical nomenclature and plant fossils. - Taxon, 59(1): 261-268.

Cohen, K. M., Finney, S. C., Gibbard, P. L., Fan, J.-X. (2013; updated): The ICS International Chronostratigraphic Chart. - Episodes, 36: 199-204. (last update February 2017; available on-line http://www.stratigraphy.org/ ICSchart/ChronostratChart2017-02.pdf)
Corbett, S. L., Manchester, S. R. (2004): Phytogeography and fossil history of Ailanthus (Simaroubaceae). - International Journal of Plant Sciences, 165: 671-690. https://doi.org/10.1086/386378

Crippa, G., Angiolini, L., Bottini, C., Erba, E., Felletti, F., Frigerio, C., Hennissen, J. A. I., Leng, M. J., Petrizzo, M. R., Raffi, I., Raineri, G., Stephenson, M. H. (2016): Seasonality fluctuations recorded in fossil bivalves during the early Pleistocene: implications for climate change. - Palaeogeography, Palaeoclimatology, Palaeoecology, 446: 234-251.

https://doi.org/10.1016/j.palaeo.2016.01.029

Drew, B. T., Sytsma, K. J. (2012): Phylogenetics, biogeography, and staminal evolution in the tribe Mentheae (Lamiaceae). - American Journal of Botany, 99(5): 933-953. https://doi.org/10.3732/ajb.1100549

Fauquette, S., Bertini, A. (2003): Quantification of the northern Italy Pliocene climate from pollen data: evidence for a very peculiar climate pattern. - Boreas, 32(2): 361369. https://doi.org/10.1080/03009480301825

Fischer, T. C., Butzmann, R. (2000): Die neogene Flora von Meleto (Valdarno, Italien). Paläobotanik, Paläoökologie und Paläoklima. - Flora Tertiaria Mediterranea, 5(6): 1-186.

Forno, M. G., Gattiglio, M., Comina, C., Barbero, D., Bertini, A., Doglione, A., Gianotti, F., Irace, A., Martinetto, M., Mottura, A., Sala, B. (2015): Stratigraphic and tectonic notes on the Villafranca d'Asti succession in the type-area and Castelnuovo Don Bosco sector (Asti reliefs, Piedmont). - Alpine and Mediterranean Quaternary, 28(1): 5-27.

Gentilini, G. (1989): The Upper Miocene dragonflies of Monte Castellaro (Marche, Central Italy) (Odonata Libellulidae). - Memorie della Società Entomologica Italiana, 67(2): 251-271 (1988).

Gregor, H. J. (1990): Contribution to the Late Neogene and Early Quaternary floral history of the Mediterranean. Review of Palaeobotany and Palynology, 62; 309-338. https://doi.org/10.1016/0034-6667(90)90093-X

Günther, T., Gregor, H.-J. (1990): Computer-Analyse mitteleuropäischer Frucht- und Samenfloren Europas, Band 2. - Documenta naturae, 50(2): 1-159.

Hably, L. (2001): Fruits and leaves of Ailanthus Desf. from the Tertiary of Hungary. - Acta Palaeobotanica, 41: 207219.

Hably, L. (2010): The Early Oligocene flora of Santa Giustina (Liguria, Italy) - Revision and comparison with the flora of the Tard Clay Formation. - Rivista Italiana di Paleontologia e Stratigrafia, 116: 405-420.

Iaccarino, S. M., Bertini, A., Di Stefano, A., Ferraro, L., Gennari, R., Grossi, F., Lirer, F., Manzi, V., Menichetti, E., Ricci Lucchi, M., Taviani, M., Sturiale, G., Angeletti, L. (2008): The Trave section (Monte dei Corvi, Ancona, Central Italy): an integrated paleontological study of the Messinian deposits. - Stratigraphy, 5(3-4): 281-306.

Kirchheimer, F. (1957): Die Laubgewächse der Braunkohlenzeit mit einem kritischen Katalog ihrer Früchte und Samen. - W. Knapp Verlag, Halle/Saale, 783 pp.

Kovar-Eder, J., Kvaček, Z., Martinetto, E., Roiron, P. (2006): Late Miocene to Early Pliocene vegetation of southern 
Europe (7-4 Ma) as reflected in the megafossil plant record. - Palaeogeography, Palaeoclimatology, Palaeoecology, 238: 321-339.

https://doi.org/10.1016/j.palaeo.2006.03.031

Kovar-Eder, J., Kvaček, Z., Ströbitzer-Hermann, M. (2004): The Miocene flora of Parschlug (Styria, Austria) - Revision and synthesis. - Annalen des Naturhistorischen Museums in Wien, 105A: 45-159.

Kowarik, I., Säumel, I. (2007): Biological flora of central Europe: Ailanthus altissima (Mill.) Swingle. - Perspectives in Plant Ecology, Evolution and Systematics, 8(4): 207-237. https://doi.org/10.1016/j.ppees.2007.03.002

Kunzmann, L., Kvaček, Z., Mai, D. H., Walther, H. (2009): The genus Taxodium (Cupressaceae) in the Palaeogene and Neogene of Central Europe. - Review of Palaeobotany and Palynology 153(1): 153-183. https://doi.org/10.1016/j.revpalbo.2008.08.003

Kvaček, Z. (2004): Early Miocene records of Craigia (Malvaceae s.1.) in the Most Basin, North Bohemia - whole plant approach. - Journal of the Czech Geological Society, 49: 161-171.

Kvaček, Z. (2007): Do extant nearest relatives of thermophile European Tertiary elements reliably reflect climatic signal? - Palaeogeography, Palaeoclimatology, Palaeoecology, 253: 32-40. https://doi.org/10.1016/j.palaeo.2007.03.032

Kvaček, Z. (2008): Whole-plant reconstructions in fossil angiosperm research. - International Journal of Plant Sciences, 169(7): 918-927. https://doi.org/10.1086/589694

Kvaček, Z., Dvořák, Z., Mach, K., Sakala, J. (2004): Třetihorní rostliny severočeské hnědouhelné pánve [Tertiary Plants from North Bohemian Brown Coal Basin]. - Severočeské doly, a. s., Chomutova; Granit, s. r. o., Praha, 158 pp. (in Czech)

Kvaček, Z., Hably, L. (2014): The Whole Plant Reconstruction of Banisteriaecarpum giganteum and Byttneriophyllum tiliifolium - A Preliminary Report. - Folia Musei rerum naturalium Bohemiae occidentalis, Geologica et Paleobiologica, 48(1-2): 1-10.

Kvaček, Z., Teodoridis, V., Gregor, H.-J. (2008): The Pliocene leaf flora of Auenheim, Northern Alsace (France). - Documenta naturae, 155(10), 1-108.

Łańcucka-Środoniowa, M. (1966): Tortonian flora from the "Gdów Bay" in the South of Poland. - Acta Palaebotanica, 7(1): 1-135.

Lanini, B. (2001): Il Messiniano evaporitico e post-evaporitico in alcune sezioni italiane e spagnole: il contributo palinologico alla ricostruzione paleovegetazionale e paleoclimatica [The evaporitic and post-evaporitic Messinian in some Italian and Spanish sections: palynological contribution to the palaeovegetational and palaoclimatic reconstruction]; MSc. thesis. - MS, Dipartimento di Scienze della Terra, Università degli Studi di Firenze, Florence, Italy, $102 \mathrm{pp}$. (in Italian) (copy in library of the Department of Earth Sciences, University of Florence)

Lu, Y., Ran, J. H., Guo, D. M., Yang, Z. Y., Wang, X. Q. (2014): Phylogeny and divergence times of gymnosperms inferred from single-copy nuclear genes. - PLoS ONE, 9(9): e107679.

https://doi.org/10.1371/journal.pone.0107679
Macaluso, L., Martinetto, E., Vigna, B., Bertini, A., Cilia, A., Teodoridis, V., Kvaček, Z. (2018): Palaeofloral and stratigraphic context of a new fossil forest from the Pliocene of NW Italy. - Review of Palaeobotany and Palynology, 248: 15-33.

https://doi.org/10.1016/j.revpalbo.2017.08.005

Magri, D., Di Rita, F., Aranbarri, J., Fletcher, W., GonzálezSampériz, P. (2017): Quaternary disappearance of tree taxa from Southern Europe: Timing and trends. - Quaternary Science Reviews, 163: 23-55.

https://doi.org/10.1016/j.quascirev.2017.02.014

Mai, D. H. (1994): Fossile Koniferenreste in der meridionalen Zone Europas. - Feddes Repertorium, 105(3-4): 207-227. https://doi.org/10.1002/fedr.19941050315

Manchester, S. R., Calvillo-Canadell, L., Cevallos-Ferriz, S. R. (2014): Assembling extinct plants from their isolated parts. - Boletín de la Sociedad Geológica Mexicana, 66(1): 53-63.

https://doi.org/10.18268/BSGM2014v66n1a5

Manchester, S. R., Chen, Z. D., Lu, A. M., Uemura, K. (2009): Eastern Asian endemic seed plant genera and their paleogeographic history throughout the Northern Hemisphere. - Journal of Systematics and Evolution, 47(1): 1-42.

https://doi.org/10.1111/j.1759-6831.2009.00001.x

Martinetto, E. (1995): Significato cronologico e paleoambientale dei macrofossili vegetali nell'inquadramento stratigrafico del Villafranchiano di alcuni settori del Piemonte (Italia NW) [Chronological and paleoenvironmental meaning of plant macrofossils in the stratigraphical framing of the "Villafranchian" unit in some districts of the Piemonte region (NW Italy)]; Tesi di Dottorato [PhD thesis]. - Dipartimento di Scienze della Terra, Università degli Studi di Torino, Torino, Italy, 149 pp. (in Italian) (printed in 100 copies, one copy in the library of the Earth Sciences Department of the Turin University)

Martinetto, E. (2003): Leaves of terrestrial plants from the shallow marine and transitional Pliocene deposits of Asti (Piedmont, NW Italy). - Bollettino della Società Paleontologica Italiana, 42: 11-75.

Martinetto, E. (2015): Monographing the Pliocene and Early Pleistocene carpofloras of Italy: methodological challenges and current progress. - Palaeontographica, Abteilung B, 293: 57-99. https://doi.org/10.1127/palb/293/2015/57

Martinetto, E., Bertini, A., Basilici, G., Baldanza, A., Bizzarri, R., Cherin, M., Gentili, S., Pontini, M. R. (2014): The plant record of the Dunarobba and Pietrafitta sites in the Plio-Pleistocene palaeoenvironmental context of Central Italy. - Alpine and Mediterranean Quaternary, 27(1): 29-72.

Martinetto, E., Mai D. H. (1996): Macrofossili vegetali [Plant macrofossils]. - In: Carraro, F. (ed.), Revisione del Villafranchiano nell'area-tipo di Villafranca d'Asti [Revision of the Villafranchian in the type-area of Villafranca d'Asti]. - Il Quaternario, 9: 73-79. (in Italian).

Martinetto, E., Monegato, G., Irace, A., Vaiani, S. C., Vassio, E. (2015): Pliocene and Early Pleistocene carpological records of terrestrial plants from the southern border of the Po Plain (northern Italy). - Review of Palaeobotany and Palynology, 218: 148-166.

https://doi.org/10.1016/j.revpalbo.2014.10.007 
Martinetto, E., Rista, C., Tarabra, E. (2000): Classificazione e ordinamento museologico di foglie di Angiosperme messiniane dell'Albese [Classification and museum storage of Messinian angiosperm leaves from the Albese district]. - Alba Pompeia, n.s., 21(1): 3-30.

Martinetto, E., Scardia, G., Varrone, D. (2007a): Magnetobiostratigraphy of the Stura di Lanzo Fossil Forest succession (Piedmont, Italy). - Rivista Italiana di Paleontologia e Stratigrafia, 113(1): 109-125.

Martinetto, E., Tema, E., Irace, A., Violanti, D., Ciuto, M., Zanella, E. (2018): High-diversity European palaeoflora favoured by early Pliocene warmth: New chronological constraints from the Ca' Viettone section, NW Italy. Palaeogeography, Palaeoclimatology, Palaeoecology, 496: 248-267.

https://doi.org/10.1016/j.palaeo.2018.01.042

Martinetto, E., Uhl, D., Tarabra, E. (2007b): Leaf physiognomic indications for a moist warm-temperate climate in NW Italy during the Messinian (Late Miocene). - Palaeogeography, Palaeoclimatology, Palaeoecology, 253: 41-55.

https://doi.org/10.1016/j.palaeo.2007.03.033

Martinetto, E., Vassio, E. (2010): Reconstructing "Plant Community Scenarios" by means of palaeocarpological data from the CENOFITA database, with an example from the $\mathrm{Ca}$ ' Viettone site (Pliocene, Northern Italy). Quaternary International, 225: 25-36.

Massalongo, A., Scarabelli, G. F. (1859): Studii sulla flora fossile e geologia stratigrafica del Senigalliese [Studies on fossil flora and stratigraphy of the Senigallia area]. - Premiata Litografia Penuti, Imola, 506 pp. (in Italian)

McNeill, J., Barrie, F. R., Buck, W. R., Demoulin, V., Greuter, W., Hawksworth, D. L., Herendeen, P. S., Knapp, S., Marhold, K., Prado, J., Prud'homme van Reine,W. F., Smith, G. F.,Wiersema, J. H., Turland, N. J. (eds) (2012): International Code of Nomenclature for algae, fungi, and plants (Melbourne Code), adopted by the Eighteenth International Botanical Congress Melbourne, Australia, July 2011. - Koeltz Scientific Books, Königstein, 240 pp.

Miller, J. S., Funk, V. A., Wagner, W. L., Barrie, F., Hoch, P. C., Herendeen, P. (2011): Outcomes of the 2011 botanical nomenclature section at the XVIII International Botanical Congress. - PhytoKeys, 5: 1-3. https://doi.org/10.3897/phytokeys.5.1850

Monegatti, P., Canali, G., Bertoldi, R., Albianelli, A. (2002): The classical Late Piacenzian Monte Falcone-Rio Crevalese section (Northern Italy): palynological evidence and biomagnetostratigraphic constraints for climatic cyclicity and local mollusc extinctions. - Geobios, Mémoire spécial, 24: 219-227.

https://doi.org/10.1016/S0016-6995(02)00061-X

Monesi, E., Mattoni, G., Scardia, G., Felletti, F., Frigerio, C., Bona, F., Tremolada, F., Francou, C., Sala, B., Raineri, G. (2016): Magnetostratigraphy of the Pleistocene marine-continental transition in the Arda River section (northern Italy): insights on the opening of the Galerian mammal migration pathway during the Late Matuyama climate revolution. - Quaternary Research, 86(2): 220-231.

https://doi.org/10.1016/j.yqres.2016.07.006
Paolucci, L. (1896): Nuovi materiali e ricerche critiche sulle piante fossili terziarie dei gessi di Ancona [New materials and critical researches on Tertiary fossil plants of the Ancona gypsum beds]. - A. Gustavo Morelli, Ancona, $158 \mathrm{pp}$. (in Italian)

Peola, P. (1899): Florula messiniana di Monte Castello d'Alessandria [Messinian florula of Monte Castello d'Alessandria]. - Bollettino della Società Geologica Italiana, 18: 44-51.

Pini, R., Castellano, L., Ravazzi, C., Raineri, L., Bona, F., Sala, B. (2014): First combined findings of in-situ fossil wood and pollen of Parrotia persica and cf. Eucommia sp. in late Early Pleistocene deposits from the northern Apennine fringe (N Italy). - In: Abstract volume $9^{\text {th }}$ EPPC, Padua, pp. 211-212.

Principi, P. (1926): Flora sarmaziana di Polenta in provincia di Forlì [Sarmatian flora of Polenta in the province of Forli]. - Atti della Società Ligure di Scienze e Lettere, nuova serie, 5(3): 1-72. (in Italian)

Ravazzi, C. (2003): Gli antichi bacini lacustri e i fossili di Leffe, Ranica e Pianico-Sèllere (Prealpi Lombarde) [The ancient lacustrine basins and the fossils of Leffe, Ranica and Pianico-Sèllere (Lombardian Prealps)]. - Consiglio Nazionale delle Ricerche, Istituto per la Dinamica dei Processi Ambientali, Milano, 175 pp.

Rio, D., Channell, J. E. T., Bertoldi, R., Poli, M. S., Vergerio, P. P., Raffi, I., Sprovieri, R., Thunell, R. C. (1997): Pliocene sapropels in Northern Adriatic area: chronology and paleoenvironmental significance. - Palaeogeography, Palaeoclimatology, Palaeoecology 135(1-49): 1-25. https://doi.org/10.1016/S0031-0182(97)00027-8

Sachse, M. (2001): Oleaceous laurophyllous leaf fossils and pollen from the European Tertiary. - Review of Palaeobotany and Palynology, 115: 213-234. https://doi.org/10.1016/S0034-6667(01)00070-7

Sakala, J. (2004): The 'Whole-Plant' concept in palaeobotany with examples from the Tertiary of northwestern Bohemia, Czech Republic with particular reference to fossil wood; Ph.D. Thesis. - MS, Institute of Geology and Palaeontology, Charles University, Prague, Czech Republic and Laboratoire de Paléobotanique et Paléoécologie, Université Pierre et Marie Curie, Paris, France, 94 pp. (copy available on-line: https://web.natur.cuni.cz/ugp/main/ staff/sakala/01-PhD_Thesis/sakala-these-finale-full.pdf)

Sordelli, F. (1896): Studi sulla vegetazione di Lombardia durante i tempi geologici [Studies on vegetation of Lombardy across geological time]. - Tipografia L. F. Cogliati, Milano, 300 pp.

Stuchlik, L. (ed.) (2001): Atlas of pollen and spores of the Polish Neogene (Vol. 1). - W. Szafer Institute of Botany, Polish Acadamy of Sciences, Kraków, 158 pp.

Stull, G. W., de Stefano, R. D., Soltis, D. E., Soltis, P. S. (2015): Resolving basal lamiid phylogeny and the circumscription of Icacinaceae with a plastome-scale data set. - American Journal of Botany, 102(11); 1794-1813. https://doi.org/10.3732/ajb.1500298

Su, T., Jacques, F. M., Ma, H. J., Zhou, Z. K. (2013): Fossil fruits of Ailanthus confucii from the upper Miocene of Wenshan, Yunnan Province, southwestern China. - Palaeoworld, 22(3); 153-158. https://doi.org/10.1016/j.palwor.2013.07.002 
Teodoridis, V., Bruch, A. A., Vassio, E., Martinetto, E., Kvaček, Z., Stuchlik, L. (2017a): Plio-Pleistocene floras of the Vildštejn Formation in the Cheb Basin, Czech Republic - a review and a new paleoenvironmental evaluation. - Review of Palaeobotany and Palynology, 467: 166-190.

Teodoridis, V., Gregor, H. J. (2001): A new Pliocene leaf flora from the Meleto Clay in the opencast mine Santa Barbara, Upper Valdarno (Central Tuscany, Italy). - Flora Tertiaria Mediterranea, 5(11): 1-28.

Teodoridis, V., Kvaček, Z., Agostini, S., Martinetto, E., Rossi, M. A., Cavallo, O. (2015a): Feather palm foliage from the Messinian of Italy (Capo di Fiume, Palena and Pollenzo near Alba) within the framework of northern Mediterranean late Miocene flora. - Acta Musei Nationalis Pragae, Series B, Historia Naturalis, 71(3-4): 301-314.

Teodoridis, V., Kvaček, Z., Sami, M. (2017b): Revision of the Messinian flora of Polenta (Romagna Apennines, Northern Italy). - Neues Jahrbuch für Geologie und Paläontologie, Abhandlungen, 283: 221-237. https://doi.org/10.1127/njgpa/2017/0638

Teodoridis, V., Kvaček, Z., Sami, M., Utescher, T., Martinetto, E. (2015b): Palaeoenvironmental analysis of the Messinian macrofossil floras of Tossignano and Monte Tondo (Vena del Gesso basin, Romagna Apennines, northern Italy). - Acta Musei Nationalis Pragae, Series B, Historia Naturalis, 71(3-4): 249-292.

Teodoridis, V., Sakala, J. (2008): Early Miocene conifer macrofossils from the Most Basin (Czech Republic). Neues Jahrbuch für Geologie und Paläontologie, Abhandlungen, 250(3): 287-312. https://doi.org/10.1127/0077-7749/2008/0250-0287

Thomé, O. W. (1885): Flora von Deutschland, Österreich und der Schweiz. - Zezschwitz, Gera, 699 pp.

Tralau, H. (1963): Asiatic Dicotyledonous affinities in the Cainozoic flora of Europe. - Kungliga Svenska Vetenskapsakademiens Handlingar, Fjärde Serie, 9(3): 1-84.

Trevisan, L. (1967): Pollini fossili del Miocene superiore nei Tripoli del Gabbro (Toscana) [Fossil pollen grains from the upper Miocene in the "Tripoli" of Gabbro (Tuscany)]. - Palaeontographia Italica, 62: 1-73 (n. ser. 32). (in Italian)
Valleri, G., Bertoldi, R., Bertini, A. (1990): Studio delle associazioni a foraminiferi e a pollini del Pliocene di Ponte a Elsa (Valdarno Inferiore, Toscana) [Studies on the Pliocene foraminifer and pollen assemblages of Ponte a Elsa (Lower Valdarno, Tuscany)]. - Bollettino della Società Paleontologica Italiana, 29(3): 321-333. (in Italian)

Vassio, E., Martinetto, E., Dolezych, M., Van der Burgh, J. (2008): Wood anatomy of the Glyptostrobus europaeus "whole-plant" from a Pliocene fossil forest of Italy. Review of Palaeobotany and Palynology, 151(3): 81-89. https://doi.org/10.1016/j.revpalbo.2008.02.006

Vieira, M., Pound, M. J., Pereira, D. I. (2018): The late Pliocene palaeoenvironments and palaeoclimates of the western Iberian Atlantic margin from the Rio Maior flora. - Palaeogeography, Palaeoclimatology, Palaeoecology, 495: 245-258. https://doi.org/10.1016/j.palaeo.2018.01.018

Viviani, V. (1833): Sur les restes de plantes fossiles trouvés dans les gypses tertiaires de Stradella prés de Pavie. - Mémoires de la Société Géologique de France, 1(1) : 129-134.

Ying, T. S., Zhang, Y. L., Boufford, D. E. (1993): The endemic genera of seed plants of China. - Science Press, Beijing, 824 pp.

Zhang, J. B., Li, R. Q., Xiang, X. G., Manchester, S. R., Lin, L., Wang, W., Wen, J., Chen, Z. D. (2013): Integrated fossil and molecular data reveal the biogeographic diversification of the eastern Asian - eastern North American disjunct hickory genus (Carya NuTT.). - PLoS ONE, 8(7): e70449. https://doi.org/10.1371/journal.pone.0070449

Zheng, Z. (1990): Végétations et climats néogènes des Alpes maritimes franco-italiennes d'apres les données de l'analyse palynologique. - Paléobiologie Continentale, 17 : 217-244.

Zhilin, S. G. (1974): Eucommiaceae. - In : Takhtajan [= Takhtadzhyan], A. (ed.), Iskopaemye tsvetkovye rasteniya SSSR [Magnoliophyta Fossilia USSR], vol. 1 : Magnoliaceae-Eucommiaceae. Nauka, Leningrad, pp. 153-154. (in Russian) 


\section{Explanations of plates}

\section{PLATE 1}

Plant fossils from the Messinian - Piacenzian of Italy. Scale bar $10 \mathrm{~mm}$, apart Fig. $5 \mathrm{~b}=1 \mathrm{~mm}$, and Fig. $9=20 \mu \mathrm{m}$. MSF $=$ catalogue numbers of the Museo Civico di Scienze Naturali of Faenza.

\section{Eucommia europaea MÄDLER}

1. Imprint of a fossil winged fruit with no margin preserved. From Monte Tondo, evaporitic Messinian, MSF2036 (photo M. Sami).

2. Compressed fossil fruit with small portion of margin preserved. From Monte Tondo, evaporitic Messinian, MSF2037 (photo M. Sami).

3. Fossil fruit, counterpart of the specimen in Fig. 2. (photo M. Sami).

4. Fossil fruit, from Stirone-Laurano, Calabrian, Museum of Fossils of Fidenza B1-13 (photo A. Orzi).

\section{Ailanthus confucii UnGER}

5a. Fossil fruit from Monte Castellaro, Messinian, Museo Paleontologico "L. Sorbini" of Fiorenzuola di Focara (photo E. Camporesi).

5 b. Detail of the attachment of the vascular bundle to the seed.

cf. Ailanthus pythii (UNGER) KOVAR-EDER et KVAČEK

6. Fossil leaf from Tossignano MSF218 (photo M. Sami).

7. Fossil leaf from Monte Tondo, Messinian, MSF1520 (photo M. Sami).

Engelhardia orsbergensis (P.WeSSEL et C.O.WEBER) JÄHNICHEN, Mai et H.Walther

8. Fossil leaf from Pollenzo pre-evaporitic Messinian.

\section{Engelhardia}

9. Fossil pollen grain from Banengo, Messinian (photo A. Bertini).

Engelhardia (sect. Palaeocarya) macroptera (BRONGNIART) UNGER

10. Fossil trilobate bract with fruit impression, from Borgo Tossignano, evaporitic Messinian, MSF30 (photo M. Sami).

11. Fossil of part of the bract bearing half of the fruit inside, split along the primary septum, from Borgo Tossignano, evaporitic Messinian, MSF246 (photo M. Sami). 


\section{PLATE 1}
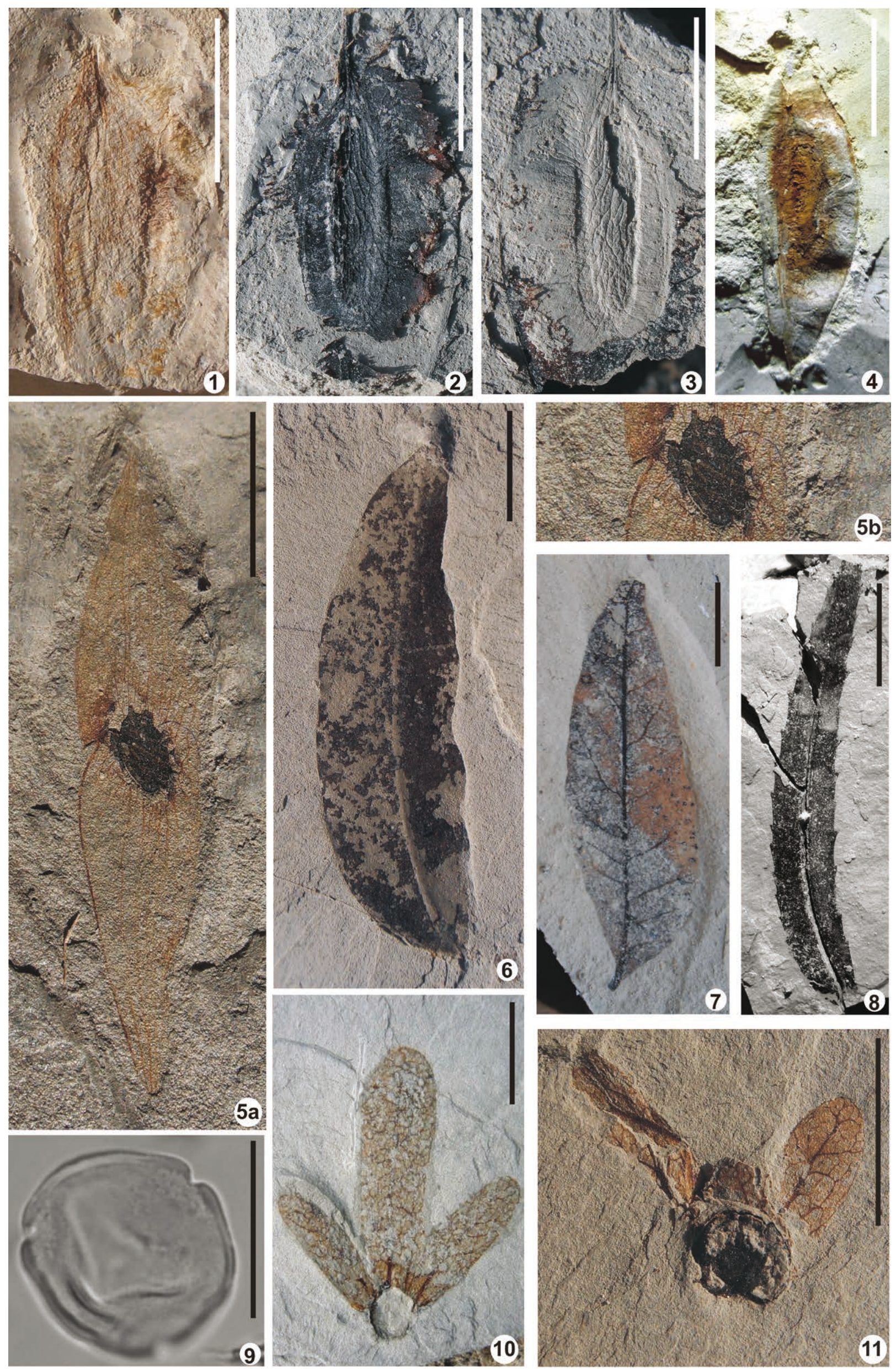